D. BATINICA

\title{
POLJOPRIVREDNA ISTRAŽIVANJA BRDSKIH I DOLINSKIH LIVADA I PASNJAKA GORSKOG KOTARA
}

\begin{abstract}
Sadržaj Predgovor -. I Uvod - A. Značaj poljoprivrednih istraživanja - B. Metodika terenskog rada 1) Uzimanje uzoraka, sušenje i vaganje sijena; 2) Hemijska analiza; - 3) Obrada materijala uvodenje pokrovne vrijednosti kao baze za preračunavanje množine pojedinih vrsta; - 4) Način rada na temelju tabela; 5) Upoređenje rezultata procjenom i rezultata vaganja. - II Pregled glavnih tipova livada i pašnjaka - opis pojedinil tipova 1) Asocijacija Bromus erectus - Plantago media Subasocijacija: a) Xerobrometum - b) Mesobrometum - 2) Asocijacija Nardetum strictae - 3) Asocijjacija Calluneto-Genistetum — 4) Asocijacija Agrostidetum vulgaris - 5) Arrhenatheretum elatioris - 6) Cynosuretum cristati - III Prinos zelene krme $i$ sijena $u$ pojedinim asocijacijama 1 uporedenje botanicke kategorizacije sijena i skrobne vrijednosti - IV Temeljne smjernice za melioracijske radove - Zalkljuçak - Iitteratura.
\end{abstract}

\section{PREDGOVOR}

Cilj je ovih istraživanja bio da se povežu botanička i poljoprivredna istraživanja te da se na taj način što potpunije iskoriste i nadopune ekonomskim momentima dotadašnja dugogodíšnja istraživanja naših botanixara.

Prot. Dr. I. H prvatu dugujem zahvalnost sto me je potaknuo na ovaj rad kao i za podatke koje $m$ j je pružio iz svojih jos neobjavljenih istraživanja. Takode zahvaljujem Ing. Slobodanu Kapetanovicu na saradnji za rad na hemijskim analizama.

\section{UVO}

Da bismo mogli pravllno ocijeniti karakter i gospodarsku vrijednost lvada 1 pašnjaka, te izyrşiti njihovo bonitiranje, moramo prouciti ne samo njihov današnji sastav, već pravesti $i$ analizu njihovog postanka i stvoriti zakljuðke o budućem njihovom razvitku pod uticajem ekoloskih faktora u podimuxju u kojem se razvijaju. Svi ovi elementi obuhvaćeni su fitocenolosłxim istraživanjima.

Kvalitet travnog pokrivača livada i pašnjaka određen je glavnim vrstama trava i leguminoza koje se na njima javljaju, te njihovim brojnim odnosom. Ovaj odnos može cesto da bude poremećen neracionalnim nacinom koristenja livade ili pasnjaka, na pr. pretjeranom ispašom, sto dovodl do procesa regresije u sastavu biljnih zajednica, kao i do degradacije samog xemljista. Pojava jednolixnih tipova Ilvada 111 pasnjaka na kojima prevladavaju rezistentne biljne vrste, koje stoka uglavnom ne jede, ill pak razvijanje pustih kamenjara i goleti, krajnje su posljedice u ovom nizu procesa. 
Pravilnim agrotehniðkim zahvatima može se spriječiti proces regresije: i sačuvati sastav biljnih asocijacija, te na taj način podici ekonomski značaj. livada i pasnjaka.

Fitocenoloskko istraživanje i proučavanje sukcesija nama omogućuje da ustanovimo tip Iivade ili pašnajka koji u izvjesnom području pokazuje narocitu vitalnost, a koji nam zbog njegovih ekonomskih osobina narocito odgovara. Poznavanje sukcesija takode ukazuje put prirodnog zatravnjivanja i: razvoja biljnog pokrivača, a time i pravilan način naše intervencije.

Prema tome, fitocenologija olakšava privredno planiranje i odreduje. ekonomske tipove livada i pasnjaka, kao i smjer gospodarenja, Fitocenolosko. istraživanje i típološko kartiranje vegetacije degradiranih područja daje nam. mogućnost da procijenimo vrijednost livada i pašnjaka, da melioracijske ladove i istraživanja vežemo za one vegetacijske tipove koji su s obzirom. na. njihovo prostranstvo i ekonomsku ulogu važni i da im na taj način damo. pravilan raspored i prioritet.

\section{A - ZNAC̈AJ POLJOPRIVREDNIH ISTRAZ̆IVAN,A}

Velika raznolikost zemljišnih i klimatskih prilika u našoj državj uslovijava mnogolikost florističkog sastava našin livada i pašnjaka. Zbog toga potrebno je vršiti pojedinačna istraživanja naših lỉvada i pašnjaka u raznim područjima. Ta raznolikost je ujedno i razlog zbog koga se iskustva stečena u stranim zemljama u pogledu unapredenja livadarstva i pašnjarstva ne mogu jednostavno primijeniti na naše prilike.

Dosada je hod nas sistematski istiažen sa poljoprivrednog gledišta vrlo. malen broj nasih livada i pašnjaka.

Polazna tacka ovih istraživanja bila je jasno omedena biljna zajednica, floristicki, ekološki i genetski povezana grupacija vrsta, kao najbolji indikator životnih prilika staništa.

Biljni pokrivač livada i pašnjaka ne pretstavlja neku slučajnu mješavinu vrsta, već jednu određenu cjelinu uslovljenu životnim prilikama. Ta se cjelina istixe mnogim osobinama: jzgledom, strukturom, florističkim sastavom, određenom prošlošçu, stalnim ekološkim prilikama itd. Na temelju florističkog sastava mogu se jasno izdvojiti osnovne vegetacijske jedinice, asocijacije.

Braun-Blanquet označuje asocijaciju kao temeljnu vegetacijsku jedinicu koja se odlikuje svojstvenim (karakteristionim) i stalnim vrstama. Svojstvene ,vrste su važne za ocjenjivanje florističce individualnosti izvjesne asocijacije. Svojstvene i stalne vrste su najbolji indikator ekologije asocijacija. Po svojstvenim i stalnim vrstama mogu se asocijacije na floristickoj osnovi klasificirati. Svojstvene (karakteristične) vrste reaguju na poremećaje ravnoteže asocijacije i na promjene $u$ njenoj ekologiji. Vrste koje dolaze $u$ svim prirodnim plohama asocijacije stalne su vrste najvećeg stepena. Tako karakterisana asocijacija pruža mogućnost rašllanjavanja u subasocijacije i varijante $a_{1}$ kao ekološki jasno olkarakterisana jedinjca omogućuje i upotrebu u praksí.

Sistematsko proučavanje pojedinił biljnih zajednica na livadama i pašnjacima omogućuje da se na osnovu malog broja karakteristienih vrsta - izdvoje jasno omedene cjeline $\mathbf{i}$ da se tako kod dovoljnog broja proukenih. povrక̧ina odredi kojem tipu - asocijaciji - livada lii pašnjak pripađa. Nakon detaljnog proucavanja sastava, životnih prilika i gospodarskog znaðenja dovoljnog broja tipično razvijenih sastojina dolazimo do zakljuxka da se sve povrşine koje imaju isti floristicki sastav, u biti podudaraju i u životnim. prilikama i da imaju približno jednako poljoprivredno značenje.

Odredivanje kojem asocijacijskom tipu livada ili pasnjaka pripada nelta livada ilf pašnjak ukazuje na to koje agrotehničke zahvate treba sprovoditi da bi se dobio $u$ odredenim uslovima. sa ekonomskog gledista najpovoljniji tip. Cim utvrdimo, na pr., na livadi neke značajne acidofilne vrste, možemo zakljuçiti ne samo kojoj zajednicl ta livada ili pašnjak pripada, nego i to da treba sprovesti kalcifikaciju i dr; odnosno nalazimo li se $u$ : području livade saševa, za koju smo utvrdilł da se razvija samo na vlažnim. staništima, znamo da treba provesti odvodnjavanje. 


\section{B - METOD TERENSKOG RADA}

\section{1) Uximanje uzoraká, sušenje, vaganje sijena}

Košenje i vaganje sijena, ispitivanje njegova sastava i hranljive vrijednosti, što se mora sve dopumiti hemijskom analizom, veona je važno za proučavanje livada i pašnjaka sa poljoprivrednog i ekonomskog gledista.

Istraživanje zelene krme i sijena vaganjem sistematski su provodili Stebler i Schröter na livadama Svajcarske. Ovom metodom vršila je 1936 godine Sorocean u u južnoj Francuskoj ispitivanje biljnih asocijacija polusuvih sredozemnih livada i utvrdila prinos suve i zelene krme kao i postotak pojedinih vrsta $u$ asocijaciji. $U$ tim svojim radovima ona se oslanjala na istraživanja $S$ teblera $i$ Schrötera i sovjetskih botaničara Larina i Poplawskaje.

Ovom metodom služili smo se i mi pri našim istraživanjima na razlicitim tipovima livada i pašnjaka u Gorskom Kotaru. Sabran je veliki broj uzoraka sijena iz razlicitih biljnih asocijacija, te je ipitivan kvan= titativni i kvalitativni sastav pojedinih tipova sijena. Povrsine za košenje uzimane su na najtipienijim mjestima za dotiłnu asocijaciju. Veličina uzete površine bila je najčesće $25 \mathrm{~m}^{2} \mathrm{Na}$ livadama se kosilo na uobicajen način, tj. kosom, dok se na pašnjacima rezalo skarama neposredno iznad zemlje. Svježa krma vagana je poljskom vagom, a zatim je susena na zemlji i ponovo vagana kao sijeno. Prinosi zelene mase i sijena preračunati su po hektaru.

\section{2) Određivanje botaničkog sastava sijena vaganjem}

Kakvoća sijena zavisi od mnogobrojnih faktora kao: floristiơkog satava, vremena kosidbe, načina spravljanja sijena, vremenskih prilika pri spravljanju sijena i načinu cuvanja.

$\mathrm{Za}$ određivanje botanickog sastava sijena na terenu uzimanil su prosječni uzorci, i to tako da su sa pokosene površine od $25 \mathrm{~m}^{2}$ sa različitih mjesta uzimane pregršti sijena i te pažljivo izmiješane. Prosječni uzorak sijena koji je iznosio 2-3 kg., sa naznakom tipa i mjesta, spreman je 'u papirnate kese.

Prilikom laboratorilkke analize sijena uzimano je od pomenutih prosječnih uzoraka po $1000 \mathrm{gr}$, a od toga su se odvajale tri probe po $100 \mathrm{gr}$. Svaka proba od $100 \mathrm{gr}$ sijena dijeljena je na sljedeće grupe:

1. dobre krmne trave

2. leguminoze

3. ostale korisne illi dobre biljke

4. kisele (šasevi) ili rđave trave

5. bezvrijedne i po zdravlje stoke škodljive biljke.

$\mathrm{Na}$ tehničkoj vagi kod svake grupe određivana je težina po vrstama. Poslije vaganja odredivan je njihov odnos $u$ procentima.

Odredivši sastav po vrstama navedenih grupa pristupilo se klasifikaoiji sijena prema krmnoj vrijednosti, po Justu. 
U prvu klasu svrstane su trave, leguminoze $i$ ostale dobre biljke, ako je njihova suma iznosila $75-100 \%$.

U drugu klasu svrstane su dobre krmne trave, leguminoze i ostalekrmne biljke, ako je njihova suma izražena u \% iznosila $50-75 \%$.

U treću klasu, ako je njihova suma u procentu iznosila $25-50 \%$.

I u cetvrtu klasu, ako je njuhova suma u procentima iznosila $0-25 \%$.

\section{3) Hemijska analiza}

Poznavamje hemijskog sastava sijena i koeficijenta svarljivosti pojedinih hranljivih materija u sijenu važno je za provodenje pravilne ishrane stoke.

Hemijsku analizu vršio je Ing. S. Kapetanović u Zavodu za hemiju Poljoprivredno-šumarskog fakulteta u Sarajevu.

\section{Priprema materijala za analizu}

Sijeno za analizu uzimano je od prosječnih uzoraka tipiěnih asocijacija. Sijeno je najprije sasječeno makazama na $1-2$ santimetra dužine, a zatim samljeveno na centrifugalnom mlinu i prosijano. Krupni dijelovi su ponovo vraćeni u mlin, dok materijal níje bio tako usitnjen da je prolazilo kroz sito promjera $1 \mathrm{~mm}$. Samljeveni uzorak preručen je u staklenu teglu, koja ję zatvorena brušnim cepom. Pri uzimanju uzoraka za analizu sadržaj tegle je svaki put dobro promiješan, a zatim je potrebna količina izvađena na porcelansku ploču. Na ploči je uzorak još miješan i poslije toga je dijagonalno uzimana potrebna količina za analizu.

Kod hemijske analize sijena određivana je vlaga, pepeo, surove bjelančevine, ciste bjelancevine, surova mast i surovo vlakno.

Vlaga je odredivana uobi ajenom metodom određivanja vlage $u$ biljnom materijalu, sušenjem na $105^{\circ} \mathrm{C}$ u trajanju od 3 sata.

Određivanje pepela vršeno je prethodnim spaljivanjem $u$ porcelanskom lonđ̌icu, a zatim žarenjem $u$ električnoj peči na $600^{\circ} \mathrm{C}$.

Surove bjelancevine odredivane su po metodi $\mathrm{KJ}$ eldahla.

Ciste bjelancevine su određivane po Grandou.

Surova mast određivana je po Soxlet $u$.

Surova vlakna određivana su po Mohačekovoj metodi.

4) Obrada materijala - uvodenje pokrovne vrijednosti kao baze. za preračunavanje množine pojedinih vrsta

Polazna tačka za utvrđivanje biljnih zajednica je sastojina. Ona je elementarna jedinica pri ispitivanju biljnih asocijacija livada i pasnjaka. Sastojina pretstavija površinu na kojoj su zastupljene vrste asocijacije koju ispitujemo, a odlikuje se ne samo jednolikošću florističkog sastava, nego i jednolikošcu klimatskih, reljefnih, edafskih i biotskih faktora.

Biljne zajednice isticu se mnogim osobinama, koje utvrđujemo neposrednim posmatranjem na samom terenu. To su analitske osobine(popis vrsta, brojnost, združenost, ucestalost, slojanje 1 fenoloski aspekt), 
za razliku od sintetskih (prisutnost, vezanost vrsta) koje dobijamo obradom $u$ zavodu, te upoređivanjem većeg broja sastojina iste zajednice $\mathbf{i}$ upoređivanjem istraživane zajednice sa ostalim zajednicama u području. Tako se biljne zajednice odlikuju i svojstvima koja se ne mogu odrediti samo na temelju istraživanja jedne sastojühe. Na temelju upoređenja većeg broja florističkih snimaka, koje smo analizirali na izabranim, dobro razvijenim sastojinama $i$ sredilli ih u asocijacijacijske tabele, određujemo sintetske osobine asocijacije, tj. vezanost vrsta, pokrovnu vrijednost i stepen prisutnosti (stalnosti).

Treba da naglasim, da sam se pri obrađivanju pokrovne vnijednosti, koja ima naročito značenje za poljoprivredna istraživanja služio još neobjavljenim asocijacijskim tabelama prof. $\mathrm{H}$ or v a t a, jer izrada asocijacijskih tabela iziskuje mnogogodišnju rad i poznavanje mnogobrojnih asocijacija ne samo u jednom području nego u raznim područjima

U tabelama su prikazane pokrovne vrijednosti vrsta u biljnim zajednicama i to: Agrostidetum valgaris, asocijacija Bromus erectus Plantago media, Nardetum strictae, Arrhenatheretum i Cynosuretum. Biljne vrste ovih asocijacija rasporedene su po pokrovnoj vrijednosti. $\mathrm{Br}$ a un-B l a $\mathrm{n}$ q u e t upotrebljava pokrovnu vrijednost pojedinih vrsta kao mjerilo za određivanje njihove važnosti u biljnirn zajednicama. Pokrovna vrijednost daje naročito uvjerljivu sliku o važnosti neke vrste u samoj zajednici.

Pod pokrovnom vrijednošću podrazumijeva se u brojkama izražena zastupljenost nelke vrste ili skupine vrsta $u$ asocijaciji. Ona se odreduje tako da se na osnovu florističkih snimaka sređenih u tabele izračunavaju za svaku vrstu srednji pokrovni postoci koji se međusobno zbroje i podijele sa brojem snimaka u tabeli. Dobijena brojka pomnoži se sa 100 i tako zaokruži. Pokrovnoj vrijednosti dodajemo kao eksponent stepen prisutnosti u obliku rimskih brojeva (I-X), i tako dobijamo jasnu sliku o raširenosti neke viste u asocijacijt. Braun-Blanquet ističe da pokrovnost daje mnogo bolju sliku o vezanosti শi važnosti vrsta $u$ biljnim zajednicama nego što je daje stalnost (nazočnost).

U razvitku nauke o biljnim zajednicama naročito je pažnja obraćena prisutnosti (stalnosti) vrsta. Prisutnost oznacuje kolikom se pravilnošcu pojedina vrsta pojavljuje u različitim sastojinama iste zajednice. S obztrom na broj i stepen prisutnosti vrsta razlikuju se pojedine biljne zajednice, pa je za svaku zajednicu potrebno odrediti koliko se vrsta i u kojem stepenu prisutnosti pojavljuje u zajednici.

U našim tabelama označen je uz pokrovnost i prisutnost kod svake vrste $i$ ekonomski značaj prema podacima iz domaće $\mathfrak{i}$ strane literature. Odmah treba da naglasim da svrstavanje vrsta u kategorije po ekonomskom značaju nije jedinstveno, pa na tom području treba još mnogo raditi i prikupljati podatke sa naših terena. U tabelama je prikazano značenje vrsta po ovim kategorijama:

Kategorija A oznałava najbolje vrste po krmnoj vrijednosti.

Kategorija $B$ označava manje vrijedne vrste po krmnoj vrijednosti Kategorija C označava bezvrijedne vrste po krmnoj vrijednosti $\dot{a}$ Kategorija $D$ oznaxava otrovne vrste. 


\section{PREGLED GLAVNIH TLPOVA LIVADA I PASNJAKA - OPIS POJEDINIH TIPOVA}

Ispitivanje biljnih zajednica na livadama i pašnjacima pretstavlja značajan doprinos za konsolidovanje krmne baze nekog kraja. To je uslov za sistematsko i plansko razvijanje stočne proizvodnje po obimu i kvalitetu.

U Gorskom Kotaru nalazimo, kako su već utvrdili I. Horvat i $i$ to asocijacija Agrostidetum vulgaris, asocijacija Bromus erectus $i$ to asocijacija Agrostidetum vulgaris, asocijacija Bromus erectum Plantago media, asoaijacija Nardetum strictae, asocijacija Calluneto Genistetum, asocijacija Anrhenatheretum elatioxils i Cynosuretum cristati.

\section{1 - Asocijacija Bromus erectus - Plantago media}

\section{Subasocijacija: a) Xerobrometum \\ b) Mesobrometum}

Asocijacija Bromus erectus - Plantago media spada, po Horvat $u$, u grupu brdskih livada i pašnjaka koje se nalaze između dolinskih livada i planinskih rudlina. Ona se razvija na vapnenačkoj i dolomitnoj podlozi, tj. na bazickim ili neutralnim tlima i pripada redu Brometalia erecti (ovsikovih livada). Ovaj tip livade, odnosno pasnjaka, razvio se najcesće na suhim, strmim obroncima i talasastim površinama koje su izvan dohvata poplavnih voda.

Jedan od važnih faktora za život i razvoj asocijacije Bxomus exectus - Plantago media je hemíjski sastav tla kao i prisustvo kalcijum karbonata. $\mathrm{Na}$ osnovi velikog broja analiza utvrdilo se da se podudara floristiðki i hemijski sastav tla. Moh a cek i Horvat utvrdili su da se pH asocijacije Bromus erectus - Plantago media kreće od 6,8 $-7,6$.

Livada Bromus erectus - Plantago media je sekundarnog postan$\mathrm{ka}$, tj. razvija se na mjestu gdje je suma uništena. U vertikalnom pogledu ovaj brdski tip livade, odnosno pašnjaka, proteže se, po H o r$v$ a $t$, od Savskih nizina do Gorskih krajeva $u$ visini do $1.200 \mathrm{~m}$. One daju manju količinu sijena od dolinskih livada, ali je kvalitet sijena mnogo bolji, jer sadrži velike kolicine leguminoza, $u$ prvon redu djetelina. Ovakav sastav sijena naročito povoljno utiče na razvoj priplodne stoke. U odnosu na hemijski sastav tla i kolicinu vlage mogu se razlim kovati uglavnom dvije subasocijácije ovog tilpa brdskih livada.

Prva subasocijacija Xerobrometum razvija se na plicem i suvljem staništu kod kojega je travni pokrnivač manje zatvoren.

Druga subasocijacija Mesobrometum razvila se na dubljem zemljisnom substratu, kao i na vlažnijem staništu kod koga je travnj pokrivac zatvorenog sklopa i pretstavlja pravu kosanicu.

Karakteristično je za ove obe subasocijacije (Xerobrometum i Mosobrometum) da ih izgrađuju pretežno trajne zeljaste biljke, dok trave rjede utič na njihovu fizjonomiju. Srodnost ovih dviju subasocijacija ocituje se u prisutnosti znatnog broja istih karakteristicnih vrsta, koje su obilno zastupljene i javljaju se s velikom vitalnosću. 
Suvlja subasocijacija Xerobrometum, rekli smo, javlja se na suvim obroncima sa razmjerno plitkim tlom. U Gorskom Kotaru obično se javlja izvan kompleksa crnogoričnih šuma i sadrži veliki broj termofilnih biljaka kao što su Teucrium chamaedrys, Dorycnium germanicum i Stachys recta, kojih u vlažnoj subasocijaciji nema.

Subasocijacija Mesobrometum javlja se u vlažnijem unutrašnjem dijelu Gorskog Kotara u području crnogorične i miješane surne, a razvija se najæesćce na dubljim tlima. Cesto se nalaze obe subasocijacije zajedno i tada suvlja zaprema strmije i pliće obronke, a vlažnija položaje s dubljim profilom tla.

Iste takve zajednice susrečemo na planinskom masivu Kupresa $u$ području Brda kraj Rilićą ná visini od $1100-1300 \mathrm{~m}$, gdje se u gornjem dijelu neposredno kraj smrčeve šume susrećemo sa subasocijacijom Mesobrometum, a u središnjem dijelu Brda, na plitkorn tlu, sa subasocijacijom Xerobrometum.

\section{Sukcesije u tipu Bromus erectus - Plantago media pod uticajem različitih faktora}

Biljne zajednice koje susrećemo u nekom području nisu stalne. One se mijenjaju i razvijaju pod uticajem klime, zemljišnih procesa, uticajem čovjeka i životinjskog svijeta. Jedne traju kraće vtijeme. druge se zadržavaju vrlo dugo, ali se ipak mijenjanju. Zbog toga biljne asocijacije treba posmatrati dinamički u njihovom procesu smjenjivanja. Takve smjene asocijacija u vremenu nazivaju se sukcesijama. Sukcesije mogu biti progresivne ili regresivne.

Gledajući dinamicki na vegetaciju livadne $i$ pašnjacke tratine, možemo naói uzroke njezina postanka i razvitka, što nam služi kao osnova za preduzimanje pravilnih agrotehnickih mjera u cilju njenog što bolijeg ekonomskog iskorišćavanja.

Istraživanjima I. Horvat a utvrdeno je da se na mjestima, gdje se u kontinentalnim podrucjima ukloni sječom suma ili sikara, razvija livadni tip Bromus erectus - Plantago media. Covjek je tu jedan od najvažnijih faktora, koji sječom potpomaže razvoj ove asocijacije Dalji razvitak ove asocijacije zavisi kako od načina njenog jskorišćavanja tako i od niza drugih faktora. Površine koje su samo pasišta, na kojima je iskljucen uticaj košenja, postepeno prelaze u šikaru, koja se prestankom ispaše razvíja u šmu. Pretjerana ispaša omogućuje rasprostranjenje biljnih vrsta koje su snabdjevene bodljama (Ononis spinosa), jakim mirisom, (Toucrium chamaedrys, Salvia pratensis), ili jakim mlječnim sokom (Euphorbia cyparissias, Euphorbia verrucosa), a doprinosi nestajanju dobrih krmnih biljaka u prvom redu leguminoza. Naprotiv đubrenjem (torenjem) prelazi asocijacija Bromus erectus Plantago media u odličnu kosanicu tipa Trisetetum flavescens. Razvitak asocijacije Bromus erectus - Plantago media mogao bi se prikazati u sljedećoj shemi:

Bazifilna suma - šikara (uticaj covjeka sjecom) - asłocijacija Bromus erectus - Plantago media - asocijacija Trisetotum flavescens (uticaj covjeka đubrenjem) - asocijacija Nardetum strictae (degradacijski stadij livade). 
Grupaclja biljaka u asocijacifi Bromus erectus - Plantago media po kategorijama, prosječnoj pokrovnosti i stepenu prisutnosti

XEROBROMETUIM

\begin{tabular}{|c|c|c|c|c|c|}
\hline 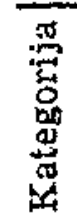 & Vrste bilja & $\begin{array}{l}\text { Pokrovnost } \\
\text { i stepen } \\
\text { prisutnosti }\end{array}$ & 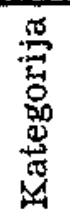 & Vrste bilis & $\begin{array}{l}\text { Pokrovnost } \\
\text { i stepen } \\
\text { prisutnosti }\end{array}$ \\
\hline
\end{tabular}

Trave

A Bromus erectus

A Koelerla pyramidata

B Brachypodium pinnatum

B Briza media

$B$ Festuca ovina

A Festuca rubra

B Danthonia calycina

A Dactylis glomerata

B Festuca capillata

B Festuca sulcata

A Poa bulbosa

$B$ Anthoxanthum odoratum

A Festuca elatior

B Sieglingia decumbens

$B$ Festuca vallesiaca

A Avenastrum pratense

A Cynosurus cristatus

A Arrhenatherum elatior

A Agrostis vulgaris

C Molinia coerulea

\section{SASEVI:}

C Carex verna

C Carex montana

C Luzula campestris

\section{Leguminoze}

A H ippocrepis comosa

B Anthyllis vulneraria

A Lotus corniculatus

B Trifoltum montanum

A Medicago falcata

C Ononis spinosa

C Genista sagittalis

C Genista Januensis

D Cytisus hirsutus

A Vicia cracea

A Trifolium pratense

A Trifolium patens

D Genista tinctoria

B Trifolium pannonicum

A Onobrychis sativa

A Lathyrus megalanthus

1040. VIII
$1030-X$

$1023-V I I I$
$572-I X$
$331-X$
$251-V$
$211-I I I$
$86-V I I I$
$20-I$
$20-I$
$20-I$

$20-I$
$1-I$
$1-I I$
$1-I$
$1-I$
$0,4-I$
$0,4-I$
$0,4-I$
$0,4-I$

501-VII

240-IV

$0,4-1$

$692-V I I I$

543-IX

$432-X$

$323-I X$

83-V

$83-\mathrm{V}$

41-II

$41-$ II

21-II

20-I

3-1

2-III

2-III

$0,4-I$

$0,4-1$

$0,4-1$

\section{MAHOVINE:}

C Thuidium sp.

190-II

$150-I$

C Hypnum sp.

90-I

20-I

$0,4-1$

$0,4-1$

\section{Ostale biljke}

C Teucrium chamaedrys

B Plantago media

C Buphthalmum salicifolium

A Galium verum

C Peucedanum oreoselinum

A Thymus serpyllum

C Salvia pratensis

C Globularla

Willkommii

C Dorycnium germanicurn

A Sanguisorba minor

C Chrysanthemum leucanthemum

B Helianthemum obscurum

A Veronica Jacquinnl

L Euphorbia cyparissias

D Linum catharthicum

A Plantago lanceolata

C Potentilla opaca

C Centaurea jacea

C Centaurea Fritschii

C Cirsium pannonicum

A Brunella laciniata

C Sedum acre

A Polygala comosa

D Ranunculus bulbosus

C Scabiosa agrestis

C Peucedanum cervaria

D Euphorbia verrucosa

C Alectorolophus

C Asperula cynanchica.

A Knautia purpurea

A Brunella grandiflora

A Veronica spicata
2004-X

910-X

821-X

784-VII

782-VIII

762-IX

$701-\mathrm{X}$

611-VIII

611-VII

434-X

$432-\mathrm{X}$

392-VIF

291-VII

271-I

263-IX

253-VII

$245-\mathrm{V}$

242-VIII

233-VIr

222-V

214-VII

193-VI

184-IX

184-VIII

175-VIII

172-III

162-VI

152-IV

142-VI

121-IV

120-IV

1LI-III 


\begin{tabular}{|c|c|c|c|c|c|}
\hline 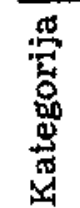 & Vrste bilja & $\begin{array}{c}\text { Pokrovmost } \\
\text { i stepen } \\
\text { prisutnosti }\end{array}$ & 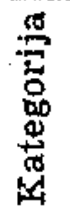 & Vrste bilja & $\begin{array}{l}\text { Pokrovnost } \\
\text { i stepen } \\
\text { prisutnosti }\end{array}$ \\
\hline
\end{tabular}

\section{Ostale biljke:}

A Brunella vulgaris

C Hieracium Hoppeanum

D Helleborus atrorubens

C Stachys betonica

C Stachys recta

A Pimpinella saxifraga

D Juniperus communis

A Hieracium Bauchini

C Orchis sambucina

B Hypochoeris maculata

C Cirsium acaule

B Primula Columnae

A Teontodon hispidus

C Viola scotophylla

C Ajuga reptans

C Carlina vulgaris

D Euphorbia virgata

A Cerastium caespitosum

A Andropogon ishaemum

B Laserpitium latifolium

C Carduus sp.

A Veronica chamaedrys

C Gymnadenia conopea

C Anthericum ramosum

C Salvia verticillata

111-III
$103-V$
$92-I V$
$83-V$
$83-V$
$82-I V$
$72-I I I$
$66-V I I$
$74-V$
$72-I I I$
$61-I I I$
$60-I I$
$44-V I$
$43-V$
$42-I I I$
$42-I I I$
$41-I I$
$41-I I$
$40-I$
$40-I I$
$40-I$
$40-I I$
$22-I I I$
$22-I I I$
$22-I I I$

C Gentiana utriculosa

B Pedicularis

brachyodonata

B Dianthus croaticus

C Centaurea variegata

C Linum tenuifolium

D Anemone nemorosa

$C$ Ophrys sp.

C Senecio spec.

B Laserpitium Siler.

D Intula hirta

B Scabiosa stricta

B Knautia arvensjs

D Linum viscosum

C Potentilla erecta

C Artennaria dioica

A Veronica officinalis

A Eryngium amethystinum

C Tunica saxifraga

C Gentiana targestina

C Aster amellus

D Verbascum sp.

B Scabiosa Fladnikiana

B Prunus spinosa

B Populus nigra

C Orobanche sp.
21-II

21-I

21-II

21-III

21-II

21-II

21-I

21-I

21-I

$21-1$

20-IX

20-I

$20-1$

$20-1$

$20-\mathrm{I}$

$20-1$

$20-1$

$20-1$

$20-\mathrm{I}$

$20+x$

20-1

20-I

20-1

20-I

2-III

Grupacija biljaka u asocijacijł Bromus erectus $\rightarrow$ Plantago media po kategorijama, prosječnoj pokrovnosti $i$ stepenu prisutnost:

MESOBROMETUM

\section{Trave:}

A Koeleria pyramidata

A Bromus erectus

B Briza media

B Brachypodium pinnatum

B Danthonia calycina

A Festuca rubra

B Festuca ovina

B Anthoxanthum odoratum

A Dactylis glomerata

A Cynosurus cristatus

A Festuca pratensis

A Agrostis ,vulgaris

A Phleum pratense

B Sieglingia decumbens

B Festuca capillata

A Arrhenatherum elatior

A POA pratensis

B Holcus lanatus

C Nardus stricta
B Festuca vallesiaca

A Poa bulbosa

$1160-\mathrm{X}$ 822-VIII

$568-\mathrm{X}$

$560-\mathrm{V}$

$402-V$

393-IX

220-VI

$163-$ VII

154-VII

$120-V I I$

93-V

90-II

61-I

42-IV

42-IV

22-III

21-III

21-II

1-I

\section{Leguminoze:}

A Lotus comiculatus

A Medicago falcata

A Vicia cracca

C Genista sagittalis

A Trifolium patens

A Trifolium repens

B Trifolium alpestre

D Ononis spinosa

D Genista tinctoria
$0,4-1$

$0,4-1$

$0,4-1$

B Trifolium montanum

1215-X

B Anthyllis vulneraria $802-X$

A Trifolium pratense 694-IX

A Hippocrepis comosa

$651-\mathrm{X}$

$332 * \mathrm{X}$

B Trifolium pannonicum

D Coronilla vaginalis

- $133-\mathrm{V}$

$131-I V$

112-IV

93-IV

21-II

20-I

$1-I$

1-Ir

$0,4-I$

$0,4-1$

C Lathyrus megalanthus

$0 ; 4-I$. 


\begin{tabular}{|c|c|c|c|c|c|c|}
\hline 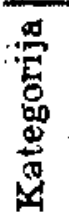 & Vrste billa & $\begin{array}{l}\text { Pokrovnost } \\
\text { i stepen } \\
\text { prisutnosti }\end{array}$ & 兽 & Vrste & bilja & $\begin{array}{c}\text { Pokrovnost } \\
\text { i stepen } \\
\text { prisutnosti }\end{array}$ \\
\hline
\end{tabular}

Mahovine:

G Mnium undulatum
C Tortella tontuosa
C Hylocomium sp.
C Fypnum spec.

Saševi:

-C Carex montana

C Carex verna

C Carex glauca

C Luzula campestris

C Luzula nemorosa

C Carex pilulifera

Ostale biljke:

B Plantago media

A Thymus serpyllum

C Salvia pratensis

C Chrysanthemum leucanthemum

C Ruphtalmum Salicifolium

C Alectorolophus major

C Teucrium chamaedrys

D Euphorbia verrucosa

D Linum catharticum

A Knautia purpurea

C Centaurea jacea

A Plantago lanceolata

B Primula Columnae

A Polygala comosa

B Filipendula hexapetala

A Crepis biennis

D Colchicum automnale

B Helianthemum obscurun

C. Globulania Willkommi i

A Brunella vulgaris

A Brunella lacinlata

D Ranunculus bulbosus .

C Phyteuma orbiculare

C Hieracium Bauhini

(C) Scabiosa agrestis

A Carum carvl

A Sanguisorba minor

A Pinpinella saxifraga

C Vioì Riviniana

A Achillea millefolium

C Daucus carota

B Dianthus croaticus

B Hypochoeris maculata

C Galium vernum

C Cirsium acaule

A Leontodon hastilis

C. Cirslum pannonicum

-C Gymnadenia conopea

$250-I$
$150-I$
$150-I$
$70-I$


$340-I I I$
$174-$ VIII
$73-I V$
$43-V$
$20-I$
$20-I$

C Sedum acre

C Lilium bulbiferum

C Galium Mollugo

C Centaurea variegata

C Coeloglosum viride

C Ornithogalum

pyrinaicum

C Erica carnea

C Potentilla erecta

C Centaurea Fritschii

B Tragopogon pratense

C Stachys betonica

C Carlina acautis

C Stachys reicta

A Veronica Jacquini

C Sesell sp.

$1169-\mathrm{X}$

812-IX

701 -VIII

685-X

$591-1 \mathrm{X}$

$502-I X$

483-V

$431-\mathrm{V}$

$384-\mathrm{X}$

376-VI

364-IX.

$313-1 \mathrm{X}$

311.IX

284-IX

281-IV

202-IV

201-V

$192-V$

160-II

$153-\mathrm{V}$

15\%-IV

145.IX

131-III

126-IX

124-VII

111-III

104-VII

$93-\mathrm{V}$

$91-V$

85-VII

82-IV

80-III

71-II

63-V

B2-III

63-III

61-III

43-VII
43-V

2-III

2-III

2-III

2-III

2-III

$2-11$

43-V

$43-\mathrm{V}$

43- $V$

42-IV

42-III

41-III

41-III

40-III

26-VII

25-VI

23-IV

22-III

22-III

22-III

21-II

21-II

21-IF

21-II

21-VI

21-II

21-II

21-II

21-Ir

21-II

21-II

20-1

20-1

20-I

20-I

20-I

20-I

20-II

20-I

20-1

20-I

4-IV

3-IV

3-IV

2-II

2-III

2-III

2-III

2-III

2-II

1-II

I-I 
U subasocijacijskom tipu Xerobrometrum iz prethodne tabele koja je izgrađena na osnovu 25 florističkih snimaka sa različitih lokaliteta. u Hrvatskoj zastupljene su trave sa 20 vrsta, leguminoze sa 13 vrsta, šaševi sa 4 vrste, mahovine sa 6 vrsta, a ostale biljke koje pripadaju različitim porodicama sa 150 vrsta.

Pokrovnost biljaka po stepenu stalnosti

\begin{tabular}{|c|c|c|c|c|}
\hline $\begin{array}{c}\text { Red. } \\
\text { broj }\end{array}$ & Grupo & $\begin{array}{l}\text { Broj } \\
\text { vrsta }\end{array}$ & $\begin{array}{l}\text { Pokrovna } \\
\text { vrijednost }\end{array}$ & Procenat \\
\hline 1 & Trave & 20 & 4629,6 & 19,56 \\
\hline 2 & Leguminoze & 16 & 2288,2 & 9,67 \\
\hline 3 & Sasevi & 4 & 786,4 & 3,32 \\
\hline 4 & Mahovine & 6 & 450,8 & 1,91 \\
\hline \multirow[t]{2}{*}{5} & Ostale zeljaste biljke & 150 & 15509,4 & 65,54 \\
\hline & Ukulpno & 196 & 23664,4 & 100 \\
\hline
\end{tabular}

Iz ovoga se vidi da zeljaste biljke imaju najveću pokrovnost 15509,4 ili $65,54 \%$, zatim dolaze trave sa pokrovnošć od 4629,6 ili $19,56 \%$ i mahovine sa najmanjom pokrovnošcu 450,8 iji $1,91 \%$.

U subasocijacijskom tipu Mesobromotum iz prethodne tabele koja je izgrađena isto tako iz 25 florističkih snimaka sa različitih Tokaliteta zastupljene su trave sa 22 vrste, leguminoze sa 16 vrsta, šaševi sa 7 vrsta, mahovine sa 6 vrsta, a ostale zeljaste biljke koje pripadaju različition porodicama sa 145 vrsta.

Pokrovnost bijjaka po stepenu stalnosti

\begin{tabular}{rlcrc}
\hline $\begin{array}{c}\text { Red. } \\
\text { broj }\end{array}$ & \multicolumn{1}{c}{ Grup e } & $\begin{array}{c}\text { Broj } \\
\text { vista }\end{array}$ & $\begin{array}{c}\text { Pokrovna } \\
\text { vrijednost }\end{array}$ & Procenat \\
\hline 1 & Trave & 22 & 4956,2 & 22,47 \\
2 & Leguminoze & 16 & 4333,2 & 19,64 \\
3 & Sašvi & 7 & 700,0 & 3,18 \\
4 & Mahovine & 6 & 641,0 & 2,90 \\
5 & Ostale zeljaste biljke & 145 & 11430,0 & 51,81 \\
\cline { 2 - 5 } & & 196 & 22060,4 & 100
\end{tabular}

I ovu subasocijaciju karakterišu zeljaste biljke sa najvećon pokrovnošóu 11430,0 ili $51,81 \%$, trave sa pokrovnošću 4956,2 ili $22,47 \%$. Upoređujući ove subasocijacije vidimo da se $u$ Mesobrometumu ističu leguminoze sa najvećom pokrovnošcu 4333,2 ili $19,64 \%$, dok ih kod subasoc jacijsksog tipa Xerobrometum ima svega 2288,2 ili $9,76 \%$. Privredna vrijednost pojedinih grupa biljaka $i$ njihovih pretstavnika na livadskoj i pašnjačkoj tratini nije jednaka.

Od svih pomenutih grupa najveći privredni značaj imaju travedobre krmne vrijednosti, $i$ to naročito pri spravljanju sijena, jer se- 
njihovo lišce pri sušenju najmanje rasipa. $\mathbf{S}$ obzirom na to treba da na prirodnim i vijestačlsim livadama prevladavaju trave $u$ odnosu na ostale grupe. U asocijacijskom tipu Bromus erectus - Plantago media trave su zastupljene od 19,56 - 22,47\% od ukupne količne svih grupa.

Druga grupa, tj. legumlinoze, pretsłavljaju biljke velike gospodarske vrijednosti zbog bogatstva $u$ bjelancevinastim i mineralnim materijama, Irojih sadrže u znatno većoj mjeri nego trave. Leguminoze ispunjavaju livadnu tratinu na preznim mjestima između bokora trave i. time stvaraju gusći travni pokrivač, nadalje obogaćujiu tlo fiksaojom azota iz vazduha, a pomoću razvijenog i vretenastog korijenovog sistema obogaćuju gornje površinske slojeve tla. hranljivim materijama na račun donjih. Leguminoze su zastupljene u asocijacijskom tipu Bromus erectus - Plantago media sa 9,67-19,64\% u odnosu na ostale grupe.

Zeljaste bijjke ostalih porodica pretstavljaju jako rasprostranjenu grupu po brojnosti i po pokrovnosti. One čine u asocijacijskom tipu Bromus erectus - Plantago media vise od 50\% (51,81 - 65,54\%) od ukupne kolicine svih grupa u zajednici. Ali u uporedivanju sa prethodnim dvjema grupama imaju najmamij privredni značaj. Mnoge su od njih nekorisne i škodljive biljke (Ranuncuhus bulbosus, Euphorbia cyparissias, Helleborus spec.), jer potiskuju korisne trave, a neke utiču nepovoljno i na kakvoću stoěnih proizvoda ili na zdravlje domaćih životinja, prouzrokujući razna oboljenja pa i smrt. Ali, među biljkama ove grupe ima i korisnih (Hypochoeris maculata, Leontodon hastilis, Sangúisorba minor) koje po svojoj hranljivoj vrijednosti ne zaostaju iza dobrih krmnih trava i leguminoza, a ponekad ih cak i prelaze.

Prema tome nije opravdano glediste da su biljke iz grupe ostalih porodica isključivo korovske i štetne.

Prisustvo zeljastih biljaka na prirodnim pašnjacima, ukoliko nisu stetne $i$ otrovne, važnije je nego za prirodne livade zbog toga što ih stoka, dok su mlade, $u$ većini slučajeva rado jede. Za livade one nemaju osobitog značaja, jer se one kod spravljanja sijena gube $u$ trinama.

Zbog velikog prisustva zeljastih biljaka, dobivaju se $u$ objema subasocijacijama velike količne trina u sijenu. Prilikom skupljanja sijena najčesce se osipa lišce sa zeljastih biljaka, tako da w sijenu ostaju samo gole stabljike. Bez obzira na to sto su u trinama cesto zastupljeni najvredniji dijelovi biljaka (odlomci lisća, cvjetova), te razne mineralne primjese, ipak prisustvo trina umanjuje krmnu vrijednost sijena.

Zeljaste biljke raznih porodica uglavnom ne dolaze $u$ obzir pri zasijavanju umjetnih livada, ali se uzimaju pni sjetvi vještačkih pašnjaka. Tako $\$$ tapledon na osnovu novih iskustava stečenih $u$ Walesu, predlaže smjese zeljastih biljaka pri sjetvi umjetnih livada $\mathfrak{i}$ to vrste koje stoka rado jede, a koje sadrže visoki procenat bjelančevina u liscu. Među takve zeljaste biljke ubrajaju se: Plantago lanceolata, Hypochooris radicata, Achillea: millefolium, Bellis perennis, Leontodon hispidus, Cichorium inthybus, i dr. 


\section{Botanička i težinska analiza sijena asocijacijskog tipa Bromus erectus - Plantago media}

Botanickka i težinska analiza sijena subasocijacijskog tipa Xerobrometum iz tabele br. 7. Uzorak sijena uzet je u području Mrzle Vodice prema Gornjem Jelenju. Izvagani uzorak sijena iznosio je 100 grama.

Vrste zastupljene u uzorku i težina pojedinih skupina:

I. Dobre livadske trave

1. Bromus erectus

. Koeleria pyramidata 10,58

3. Festuca, vallesiaca 3,26

4. Festuca rubra 3,96,

5. Briza media

0,42

$43,90 \mathrm{gr}$.

\section{Leguminoze}

1. Lotus corniculatus

2. Trifolium montanum

3. Hippocrepis comosa

$\begin{array}{r}3,52 \mathrm{gr} \\ 6,74 \mathrm{~g} \\ 0,76 \% \\ \hline 11,02 \mathrm{gr} .\end{array}$

III. Ostale korisne ili dobre biljke

1. Scabiosa agrestis

2. Veronica jacquini

3. Galium lucidum

4. Thymus serpyllum

5. Pimpinella saxifraga

6. Asperula cynanchica

7. Hieracium Batuchini

8. Helianthemum obscurum 0.18 "

$14,10 \mathrm{gr}$.

0,22 "

0,66 ,"

1,62

0,04

0,38,

1,84,

$19,04 \mathrm{gr}$.
IV. క̆ă̌evi

I Carex verna

$1,68 \mathrm{gl}$.

V. Bezvrijedne ill po zaravlje stoke گ̌kodljive blljke

1. Salvia pratensis

$1,10 \mathrm{gr}$.

2. Phyteuma orbicularis

3. Orchis spec.

3,28 ,

0,14 ,

4. Gentiana utriculosa

0,26,

5. Antennaria dioica $0,74 "$

6. Rhynanthus minor 1,20 "

7. Centaurea jacea

1,84,

8. Chrysanthemum leucant. 0,35 ,

9. Inula hirta

5,99 ,

10. Mahovine

$\frac{0,02 \mathrm{ng}}{15,02 \mathrm{gr} .}$

VI. Trine

$9,34 \mathrm{gr}$.

Botanička kategorizacija sijena prema krmnoj vrijednosti:

\begin{tabular}{llccc}
\hline Red. & \multicolumn{1}{c}{ G r u p e } & $\begin{array}{c}\text { Težina u } \\
\text { gramima }\end{array}$ & Procenat & Klasa \\
\hline 1. & Dobre livadne trave & 43,90 & 73,96 & \\
2. & Leguminoze & 11,02 & & II \\
3. & Ostale korisne ili dobre biljke & 19,04 & \\
4. & Kisele (Saševi) ili rđave trave & 1,68 & \\
5. & Bezvrijedne i po zdravlje \\
stoke skodljive biljke & 15,02 & 26,04 \\
6. Trine & 9,34 & & \\
\hline
\end{tabular}

Botanička i težinska analiza siłjena subasocijacijskog tipa Mesobrometum iz tabele br. 8. Uzorak sijena uzet iz Crnoluškog Zelina. Izvagani uzorak sijena iznosio je 100 grama. 
Vrste zastupljene $u$ uzorku $i$ težina pojedinih skupina:

\section{Dobre livadne trave:}

1. Bromus erectus

$14,24 \mathrm{gr}$.

2. Koeleria pyramidata

3. Dactylis glomerata

4. Festuca rubra

5. Agrostis vulgaris

6. Danthonia calycina

7. Briza media

8. Cynosurus cristatus

9. Sieglingia decumbens

9,36,

8,82,

8,04,

6,40

4,46 ,

1,24 "

1,40 ,

0,24,

$54,20 \mathrm{gr}$.

\section{Leguminoze:}

1. Trifolium montanum

2. Lotus corniculatus
III. Ostale korisne ili dobre biljke:

1. Achillea millefolium

2. Thymus serpyllum

$0,54 \mathrm{gr}$.

3. Folygala vulgaris

0,42

0,80

4. Helianthemurn obscurum $0,66 "$

5. Galium spec.

$\frac{0,16:}{2,58 \mathrm{gr} .}$

1v. Saševi:

$0 \mathrm{gr}$.

V. Bezvrijedne i po zdravlje stoke škodljive biljke:

1. Potentilla tormentilla $0,84 \mathrm{gr}$.

2. Centaurea jacea 11,72 ,

3. Genista sagittalis 1,20 ,"

4. Colchicum autumnale 1,34 ,"

5. Rhynanthus maior 0,94 ".

6. Salvia pratensis

8,30,

$24,34 \mathrm{gr}$.

$3,14 \mathrm{gr}$.

Botanička kategorizacija sijena prema krmnoj vrijednosti:

\begin{tabular}{|c|c|c|c|c|}
\hline $\begin{array}{l}\text { Red. } \\
\text { br. }\end{array}$ & $G \times \mathbf{p} \mathbf{e}$ & $\begin{array}{l}\text { Težina u } \\
\text { gramima }\end{array}$ & Procenat & Klasa \\
\hline $\begin{array}{l}1 . \\
2 . \\
3 . \\
4 . \\
5 . \\
6 .\end{array}$ & $\begin{array}{l}\text { Dobre livadne trave } \\
\text { Leguminoze } \\
\text { Ostale korisne ili dobre biljke } \\
\text { Kisele (saševi) ili rdave trave } \\
\text { Bezvrijedne i po zdravlje } \\
\text { stoke škodljive biljke } \\
\text { Trine }\end{array}$ & $\begin{array}{c}54,20 \\
15,74 \\
2,58 \\
- \\
24,34 \\
3,14\end{array}$ & 72,52 & II \\
\hline
\end{tabular}

Vaganje daje vrlo zanimljivu sliku o sastavu sijena, ali bi trebalo izvršiti veći broj vaganja, da bi se dobila prava slika o težinskom učešcu pojedinih gmupa i pojedinih vrsta u grupama.

Detaljni floristicki sastav subasocijacije Xenobnometum i Mesobrometum daju nam tabele koje su izrađene na temelju neobjavljenih istraživanja prof. Horvat a, a ujedinjuju po 25 snimaka sa razlícitila lokaliteta Hrvatske.

\section{2 - Asocifacija Nardetum structae}

Asocijacija Nardetum strictae zastupljena je na svim planinama u našoj zemlji, gdje zauzima sad veće sad manje površine. U odnosu na reljef ova asocijacija javlja se na ravnim i na strmim terenima. Asocijacija Nardetum strictae razvija se najbolje na silikatnoj podlozi, ali se nalazi i povrh vapnenačke podloge, ako su u gornjem površinskom sloju tla isprane baze. $\mathrm{Na}$ osnovi analiza tla (Moh a ček Horvat) utvrđeno je da se ova biljna zajednica javlja na thima cija se reakcija kreće između 4,2 - 5,5 pH: Granično područje u kome se gube bazifilne vrste $i$ pojavljuju acidofilne je $5,5-6,0 \mathrm{pH}$. 
Asocijacija Nardetum strictao razvija se iz svih tipoya livada i proizlazi iz različitih asocijacija ukolikso dođe do zakiseljavanja tla. Zato je nalazimo u području najrazličitijih asocijacija, na raznoj nađmorskoj visini i na raznoj podlozi. Stoga je razumljivo da se pojedine varijante ove asocijacije razlikuju, iako po dominantnoj vrsti "tvrdačik (Nardus stricta) izgledaju naoko posve jednake.

Horvat u svom radu (Biljne zadruge planinskih pašnjaka, 1946) razlikuje tri skupine asocijacijskog tipa Nardetum strictae. Kao prvi je planinski tip asocijacije Nardetum strictae na silikatnoj podlozi, koji zauzima velika prostranstva, kako na ravnim tako it na talasastim i strmim terenima. U njemu rastu najčešce sljedeće vrste: Potentilla aurea, Arnica montana, Luzula multiflora, Festuca rubra, Anthoxanthum odoratum i Leontodon hastilis. Takav tip asocijacije pokriva velike površine na Vranici i na Sar-Planini. Drugi tip Nardetum strictae raširen je na vapnenačłzom gorju, kao što su Plješevića, Bjelašnica, Velebit, Dinara i Durmitor. Ovaj tip Nardetum strictae razvija se na dubljim tlima vrtaca u kojima su se isprale baze i tlo zakiselilo. Ovaj tip je vrlo oskudan u vrstama. U njemu se susrećtu najčešce sljeđeće vrste: Agrostis vulgaris, Antennaria dioica i Festuca rubra. Treći tip Nardetum strietae javlja se na vlažnim i močvarnim staništima uz vrela na silìkatnim geološkim podlogama. U njemu se javljaju mnoge barske tresetne vrste. Kod nas ovaj tip susrećemo u Gorskom Kotaru, na Vranici, na Sar-Planini i na Peristeru.

Asocijacija Nardetum strictae u Gorskom Kotaru pokriva znatne povrł̧ine i to ne samo u planinskoij zoni nego prodire i u niža područja, kao što su Bijele Vodice, Mrzle Vodice i Suha Rječina. Uza svu homogenost tipa Nardetum strietae, koja izvire iz dominantne vrste tvrdače - Nardus stricta, ipak se javljaju razlike u pojedinim sastojinama, koje zavise od nadmorske visine, načina iskorišćavanja, zatim od toga u kakvom se području nalaze $i$ iz kakve je asocijacije nastao. Dok je asocijacilja Nardetum strictae na Bjelašnici, Plješevici i Velebitu čsto član sukcedanog niza Festucetum pungentis, Festuca rubra asocijadije, na Snježniku je član niza Caricetum fïrmae - Festuca amethystina asocijacije, a $\mathfrak{u}$ nižem brdskom pojasu nastaje iz asocijacije Agrostidetum vulgaris i Bromus erectus -, Plantago media. $\mathrm{Na} \mathrm{kraju}$ javlja se i kao inicijalni stadij $\mathbf{i}$ clan kompleksa asocijacije tipa Vriština - Calluneto - Genistetum, koji se susreće u Suhoj Rječini.

Sukcesije u tipu Nardetum strictae pod uticajem različitih faktora

Sukcesije u asocijacijskom tipu Nardetum strictae nastaju kao posljedica promjene prirodnih uslova rasta $i$ razvoja, ili kao rezultat nacina iskorišcavanja travne tratine. Razvitak asocjjadije Nardetum strictae u brdskom pojasu u njegovom dinamičkom razvitku može se prikazati u sljedećoj shemi:

Acidofilna šuma - sječine (uticaj čovjeka sječom)

Sikara ili vriština - Nardetum strictae (degradacijski stadij livade) Oranica - (uticaj covjeka obradom) - stadij korovskih biljaka - Agrostidetum (tip dolinske livade) - Nardetum strictae (degradirani stadij livade). 
Grupacija biljaka u asocijaciji Nardetum strictae po kategorijama, prosječnoj pokrovnosti i stepenu prisutnosti

NARDETUM STRICTAE

\begin{tabular}{|c|c|c|c|c|c|}
\hline 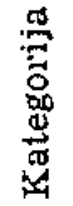 & Vrste bilja & $\begin{array}{l}\text { Pokrovnost } \\
\text { i stepen } \\
\text { prisutnosti }\end{array}$ & 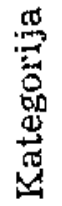 & Vrste bilja & $\begin{array}{l}\text { Pokrovnost } \\
\text { i stepen } \\
\text { prisutnosti }\end{array}$ \\
\hline
\end{tabular}

Trave:

C Nardus stricta

A Festuca rubra

B Sieglingia decumbens

B Festuca capillata

B Briza media

A Agrostis vulgaris

B Anthoxanthum odoratum

B Festuca amethystina

B Deschampsia flexuosa

$B$ Holcus

Saševi:

C Carex pilulifera

C Luzula campestris

C Carex verna

C Luzula nemorosa

\section{Leguminoze:}

A Trifolium spec. div.

A Lotus corniculatus

C Genista sagittalis

Mahovine:

C Dicranum

C Polytrichum formosum

C. Cladonis spec.

$5375-\mathrm{X}$
$1257-I X$
$347-\mathrm{VIII}$
$1344-\mathrm{VII}$
$128-I V$
$471-$ IV

$221-$ IV
$63-$ II
$219-$ II
$1-$ II

$67-$ VII
$67-$ VII.
$4-$ IV
$1-$ II

$224-V I I$

4-IV

$440-V I$

$220-\mathrm{V}$

67-VII

1-II

\section{Ostale biljke:}

C Potentilla tormentilla 1781-IX

C Arnica montana 878-VIII

A Alchemilla vulgaris 536-VIII

C Antennaria dioica

C Hieracium pilosella

C Centaurea jacea

A Polygala vulgaris

A Achillea millefolium

287-IX

252-VIII

129-VII

$129-V I I$

128-VII

125-VI

$128-V I$

63-III

65-IV

4-IV

63-II

63-II

63-II

5-VI

3-III

3-III

3-III

3-III

3-III

1-II

1-II

1-II

67-VII

$66-\mathrm{VI}$

3-IV

2-III

U našoj tabeli prikazana je pokrovna vrijednost vrsta $u$ asocijaciji Nardetum strictae, gdje se sa najvećom pokrovnošću ističu trave.

$\mathrm{Na}$ temelju tabele koja je izrađena iz 19 floristickih snimaka razlicitih lokaliteta u Gorskom Kotaru zastupljene su trave sa 9 vrsta, šaŠevi sa 4 vrste, leguminoze sa 3 vrste, mahovine sa 3 vrste, a ostale. biljke koje pripadaju različitim porodicama sa 31 vrstom. Trave imaju najveću prosječnu pokrovnost. 9.424, zatim ostale biljke sa 5.346 , leguminoze 688, a šă̌vi sa 139.

Pokrovnost biljaka izražena $u$ proncentima i to:

$\begin{array}{lrrrcrr}\text { Trave } & 9429 & \text { izračunato } & \text { u } & \text { procentima } & \text { iznosi } & 60,50 \\ \text { Leguminoze } & 668 & \text { " } & \text { " } & \text { ". } & " & 4,28 \\ \text { Saševi } & 139 & " & " & " & " & 0,90 \\ \text { Ostale biljke } & 5346 & " & " & " & " & 34,32\end{array}$


Botanička i težinska analiza sijena asocijacijskog tìpa Nardetum striotae

Uzorak sijena uzet sa livade Gločevac kod Crnoluškog Zelina u tabeli br. 12. Odvagani uzorak sijena iznosio je 100 grama, Povrsina nije najtipičnija, jer je bila pred nekoljko godina dubrena.

Vrste zastupljene $u$ uzorku i težina pojedinih skupina:

I. Dobre livadne trave:

1. Agrostis vulgaris

2. Festuca rubra

3. Holcus lanatus

4. Sieglingia decumbens

5. Anthoxantum odoratum

vI. Saševi:

1. Lazula campestris

$2,12 \mathrm{gr}$.

2. Carex pillulifera

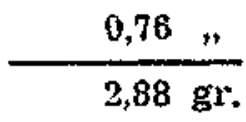

V. Bezvrijedne ilf po zdravlje stoke skodljive biljke:

II. Leguminoze:

1. Trifolium repens

2. Lotus corniculatus

$\begin{array}{r}0,80 \mathrm{gr} \\ 0,20 \mathrm{~m} \\ \hline 1,00 \mathrm{gr}\end{array}$

III. Ostale korisne ili dobre biJjke:

1. Veronica officinalis

2. Taraxacum officinale

$4,76 \mathrm{gr}$.

3,88

3. Campanula patula

4. Thymus serpylhum

5. Achillea millefolium

6. Pimpinella alpestris

7. Galium anisophyllum

8. Stellaria graminea

2,28

1,16

1,16

0,56,

0,04,

0,40

$14,24 \mathrm{gr}$.

1. Genista sagittalis

2. Potentilla tormentilla

3. Nardus stricta

4. Ranunculus acer

5. Calluna vulgaris

6. Mahovine

VI. Trine:

$4,58 \mathrm{gr}$.

Botanička kategorizacija sijena prema krmnoj vrijednosti:

\begin{tabular}{lrrr}
\hline \multicolumn{1}{c}{ Red. } \\
broj
\end{tabular}

\section{3 - Asocijacija Calluneto-Genistetum (vriština)}

Asocijacija Calluneto - Genistetum pokriva u sumskim čistinama tu i tamo znatne površine. Na nekim podruxjima u Gorskom Kotaru uz vrijes - Calluna vulgaris dominira i bujad - Pteridium aquilinum, pa se zbog jedne jll druge dominantne vrste takve površine nazivaju vristine ili bujadnice, koje se iskorišcavaju kao paśnjaci ili kose za stelju.

S obzirom na geološku podlogu na kojoj su se razvijaju javljaju se vrištine kako na vapnenackoj podlozi (Erica carnea, Rhododendron hirsutum i Genista radiata) tako i na silikatnoj podlozi (Jưniperus nana, 
Bruchenthalia spiculifolia $i$ dr.J. Ove acidofilne biljne zajednice nastaju kao početni stadij na vrlo plitkom kamenitom tlu, siromašnom u vapnu, ali se $u$ našem izrazito vapnenačkom i dolomitnom području razvijaju redovno i pošto se stvorila dublja naslaga tla u kojem su $u$ gornjem sloju isprane hranljive materije i kalcium karbonat. Vrištine u brdskom pojasu pokrivaju cesto vece povrsine, ali je njihovo gospodarsko značenje malo, jer odrvenjeni biljni dijelovi u obliku grmova nemaju hranljivu vrijednost trava, leguminoza i zeljastih biliaka.

Za vristinu su, po Horvatu, dominantne vrste: Ptendidum aquilinum i Calluna vulgaris, a od svojstvenih vrsta su Genista pilosa, Genista germanica $i$ Baeomyces roseus. Ističe se velik broj pratilica, koje pokazuju da je vriština izrazito acidofilna biljna zajednica, dok se samo po neka bazifilno neutralna vrsta javlja kao ostatak nekadašnjih zajednica, ili lokalno razvijena kao strana primjesa na vapnenackoj podlozi unutar vrištine. Od trava zastupljene su: Nardus stricta, Festuca capillata, Agrostis vulgaris i Anthoxanthum odoratum, a od leguminoza Genista pilosa, Genista germanica, Ononis spinosa, Trifolinum campestre i Trifolium repens. Od zeljastih biljaka Centaurea jacea, Euphorbia spec.. Carlina vulgaris, Pteridium aquilinum, a od grmića Calluna vulgaris. U dijagnostičkom pogledu najvažnija vrsta je Calluna vulgaris, jer određuje razvitak $\mathfrak{i}$ strukturu tla, pošto je vezana za kiselo zemljište. Po $\mathrm{H}$ orvatu i $\mathrm{M}$ oh a č e k u pH se kreće izmedu 3,6-6 pH.

Razvoj ove biljne asocijacije dinamički posmatran izgleda ovako: vriština se razvija na dubokim tlima, ali isto tako može se razvijati i na plitkim čim se tlo zakiseli is gornjih površina ispere kalcijum karbonat. Eläminiranjem paše vriština prelazi u šikaru, odnosno sumu. Đubrenjem, narocito torenjem, prelazi $u$ asocijacijski tip Agrostidetum vulgaris.

\section{Botanička i težinska analiza sijena asocijacijskog tipa Calluneto - genistetum}

Uzorak sijena uzet sa livade-pašnjakła na Bijelim Vodicama $u$ tabeli br. 15. Izvagani uzorak sijena iznosio je 100 grama.

Vrste zastupljene u uzorku i težina pojedinih skupina:

I. Dobre livadne trave:

1. Agrostis vulgaris

2. Festuca rubra

3. Festuca capillata

$16,12 \mathrm{gr}$.

9,54

4. Anthoxanthum odoratum 0,42 "

5. Sieglingia decumbens 2,44 "

$31,00 \mathrm{gr}$.

II. Leguminoze:

$0,00 \mathrm{gl}$.

III. Ostale korisne ili dobre biljke

1. Achillea millefolium $0,44 \mathrm{gr}$.

2. Hieracium piloselia 0,06 "

3. Galium verum

4. Polygala vulgaris
V. Bezvrijedne lli po zdravlje stoke šlkodtjlve biljke:

$1,64 \mathrm{gr}$.

IV. Saševi I situine:

1. Luzula campestris $0,80 \mathrm{gr}$.

1. Luzula campestris $0,80 \mathrm{gr}$.
1. Calluna vulgaris

2. Nardus stricta

3. Potentilla tormentilla

4. Centaurea jacea

5. Pteridium aquilinum

6. Rhynanthus maior

7. Antennaria dioica

8. Genista saglttalis

9. Arnica montana

10. Populus spec. (lisce)

11. Mahovine

Vx. Trine:

$16,74 \mathrm{gr}$.

20,88 ,

4,54 "

1,38 "

9,98 ",

1,68 ,

$1,56 "$

1,42 "

3,14 ,

$1,34, "$

0,32

82,98 gr.

$3,58 \mathrm{gr}$. 
Botanička kategorizacija sijena prema krmnoj vrijednosti:

\begin{tabular}{lccc}
\hline $\begin{array}{c}\text { Red. } \\
\text { broj }\end{array}$ & Težina u gramima & Procenat & Kiasa \\
\hline 1. Dobre trave & 31,00 & & \\
2. Leguminoze & 0,00 & 34,86 & III \\
3. Ostale korisne ili dobre biljke & 1,64 & & \\
4. Kisele (Šaševi) ili rđave trave & 0,80 & & \\
5. Bezvrijedne ili po zdravlje stoke & 62,98 & 65,14 & \\
S.kodljive biljke & 3,58 & & \\
6. Trine & &
\end{tabular}

4 - Asocijacija Agrostidetum vulgaris

O asocijaciji Agrostidetum vulgaris nije dosada ništa publicirano pa su podaci erpeni iz rukopisa prof. Horvata. Ona se razvila na silikatnoj podlozi, a rjeđe se nalazi na dubljem tlu povrh vapnenca. Veće površine zaprema u prirodno dubrenim uvalama suvljeg tipa, ili na mjestima nekadašnjih njiva, na dubljem zemljišnom substratu.

Asocijacija pripada svezi Arrhenatherion elatioris. Ova pripadnost proizlazi od vrsta: Trisetum flavescens, Flolcus lanatus, Cynosurus cristatus, Dactylis glomerata, Bromus racemosus, Trifolium pratense, Trifolium repens, Trifolium campestre, Leontodon autumnalis, Crepis biennis i Alectorolophus.

U asocijaciji Agrostidetum vulgaris u velikoj su mjeri zastupljene trave, naročito Agrostis vulgaris, koja se u doba cvjetanja već iz daljine ističe plavom bojom. Od ostalih trava raširene su naročito folcus lanatus, Festuca rubra i Dactylis glomerata, od leguminoza Trifolium pratense, Trifolium repens i Trifolium campestre. Uz trave $i$ leguminoze ističu se i mnogobrojne zeljaste vrste, npr. Scabiosa agrestis, Centaturea jacea, Leucanthemum vulgare, Crepis biennis i Leontodon automnale, ali njihov udio u izgradnji zajednice zaostaje za travama.

\section{Sukcesije u tipu Agrostidetum vulgaris} pod uticajem mnogohrojnih faktora

Asocijacija Agrostidetum vulgaris uslovljena je uglavnom antrom pogeno. Ova asocijacija nastala je nakon preoravanja i đubrenja iz prvobitne acidofilne.livade tipa Nardetum strictae ili iz vristine. Da je tako, potvrđuje činjenica da se na rubovima nepreoranih površina zadržao najtipienniji oblik asocijacije Nardetum strictae, sa vrstama Nardus stricta, Arnica montana, Genista sagittalis, Festuca capillata if dr. Osim toga smjenjuje se najveći dio livada $s$ oranicama, što se može vidjeti po razoricama kao posljedicom obrade i sigurnim znakom zatravljenih oranica.

Razvitak livade Agrostidetum vulgaris $u$ dinamixkom razvitku vegetacije Gorskog Kotara mogao bi se prikazati u sljedećoj shemi:

suma jele (Abieto - Blechnetum) - sjecina (uticaj čovjeka sječom) sikara i vriština - Nardetum strictae (prirodni razvitak livade pod uticajem paše 1 košenja) - oranica (uticaj covjeka obradom) - stadij korovskih biljaka (Poa trivialis - Trifolium) - Agrostidetum (tip dolinske livade) - Nardetum strictae (degradirani stadij livade)." 
Sječom šume razvila se dakle kisela livada, ali je čovjek izmijenio ekstremnu sliku kiselog tipa Nardetum strictae, preoravši veliki broj tih površina i na njima uzgajajući, uz prethodno đubrenje stajskim i umjetnim đubrivom, kulturno bilje (najčescée krompir i zob). Poslije njivskih kultura prepušta se oranica redovno samozatravljivanju ili se ponekad zasijava trinama. U početnim stadijima livade, poslije napustanj. kultura, zastupljene su nejednoliko i šaroliko biljne vrste, dok u kasnijim stadijima dobija livada vrlo jednoličan izgled. U prvoj godini rastu na napuštenim oranicama mnogobrojne zeljaste vrste, a tek u kasnijim godinama korisne trave i biljke, koje daju dobru krmu. Uzrok je tome, pored ostalog, što trine sijena sadrže često vrlo mnogo sjemena zeljastog bilja, a manji postotak zrelog sjemena dobrih trava. Osim toga unosi se sa trinama i sjemenje mnogih bazifilnih vrsta, koje potiču od sijena drugih tipova naročito asocijacije Bromus-erectus - Plantago media, koji je često na sjenicima pomiješn sa sijenom tipa Agrostidetum vulgaris. Od zeljastih vista nalaze se u trinama najčesce Alectorolophus, Centaurea jacea, Scabiosa agrestis, Leucanthemum vulgare, Crepis biennis, Ranunculus acer, Stellaria graminea, Rumex acetosa, a od trava Holcus lanatus i Bromus racemosus.

Da bismo dobili jasnu sliku o početnim stadijima nejednoliko raspoređenih biljnih vrsta, koje susrećemo pri samozatravljivanju, tj. pri postanku livade bez zasijavanja trinama (bez učešća covjeka) moramo se pobliže upoznati sa izvjesnim biološkim i ekološkim osobinama razlicitih vrsta biljaka, koje imaju prvorazrednu ulogu u pedološkim procesima.

Najveći dio livadne tratine u stadijumu mladosti pretstavlja jednogodišnje zeljaste biljke iz različitih familija. Ove zeljaste biljke razmnožavaju se sjemenom (Alectorolophus, Leunchanthemum vulgare, Stellaria graminea, Scabiosa agrestis, Bromus mollis, Ranunculus acer, Rumex acetosa). Manje su rasprostranjene dvogodišnje i višegodišnje biljke zbog toga što im tlo koje se svake godine obrađuje onemogućava razvitak.

U daljem stadijumu razvitka biljnog pokrivača livadne tratine najveći broj jednogodišnjih biljaka izumire i nastupa stadij vrsta sa prizemnim rozetastim lišćem, koji se razvija iz snažnog korijenja. Ovu misao razradio je $\mathrm{Viljams}$ u teoriji busenastog procesa. Ovaj stadij karakteriše se time što korjenje ovih biljaka ide duboko u tlo i neovisno je od kolicine atmosferskih taloga, jer koristi vlagu dubljih slojeva tla pomoću vretenastog korijena; koji seže katkad veoma duboko. Kad ove biljke poslije donošenja sjemena izumru, dolazi do mineralizacije njihovih biljnih ostataka. Kao produkt anaerobnog raspadanja organskih materija stvaraju se humino-amonijačne kiseline. Ove kiseline lako se rastvaraju u vodi $\mathfrak{i}$ ispunjavaju praznine gdje je bio korijen $\mathfrak{i}$ time se slaže humin i ulmin. Tlo ima veliki kapacitet za vodu i dobru aeraciju, pa se stvaraju uslovi za razvoj rizomnih biljaka, tj. stadij Poa trivialis - Trifolium. Nakon ovog stadija aerobni proces rastvaranja omogućen je samo u povrßinskom sloju. Taj stadij karakterisan je asocijacijom Agrostidetum vulgaris, gdje su smanjeni dinamički procesi, što se ispoljava u jednolixnom tipu livade sa dominantnom travom Agrostis vulgaris. U daljem procesu nagomilavanja mrtve organske materije sve- 
dena je aeracija na minimum i time dublje korijenje ne može da bude podvrgnuto procesu razlaganja, te nastaje stadij livade Nardetum strictae.

Grupacije biljaka a asocijaciji Agrostidetum vulgaris po kategorijama, prosječnoj pokrovnosti i stepenu prisutnosti

\begin{tabular}{|c|c|c|c|c|}
\hline 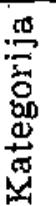 & Vrste bilja & $\begin{array}{c}\text { Pokrovnost } \\
\text { i stepen } \\
\text { prisutnosti }\end{array}$ & Vrste bilja & $\begin{array}{l}\text { Pokrovnost } \\
\text { i stepen } \\
\text { prisutnosti }\end{array}$ \\
\hline
\end{tabular}

\section{Trave}

A Agrostis vulgaris

A Festuca rubra

B Anthoxanthum odoratum

B Holcus lanatus

A Trisetum flavescens

B Briza media

A Cynosurus cristatus

A Dactylis glomerata

B Bromus racemosus

A Festuca pratensis

B Sieglingia decumbens

A Arrhenatherum elatius

A Phleum pratense

C. Nardus stricta

B Festuca capillata

B Bromus mollis

A Bromus erectus

B Festuca ovina

A Lolium perenne

A Poa pratensis

A Poa bulbosa

A Poa trivialis

B Brachypodium pinnatum

\section{Leguminoze}

A Trifolium pratense

A Trifolium campestre

A Trifolitum repens

A Lotus corniculatus

A Anthyllis tricolor

A Vicia cracca

C Genista sagittalis

A Lathyrus pratensis

A Medicago lupulina

D Genista tinctoria

B Trifolium montanum

A Trifolium patens

B Trifolfum alpestre

\section{Saševi}

C Luzula campestris

C Luzula nemorosa

$5340-X$
$1640-X$

$1594-X$
$1344-X$
$1189-X$
$108-I X$
$519-X$
$409-I X$
$206-V I$
$97-V I$
$66-V I$
$64-I I I$
$36-V I$
$34-I V$
$8-V I I I$
$5-V I$
$3-I I I$
$2-I I$
$1-I I$
$1-I$
$1-I$
$I-I$
$1-I$

$1297-X$

525-IX

$318-1 X$

$160-V I I$

34-III

$7-V I I$

3-III

1-II

1-II

1-I

$1-I$

$1-1$

$1-I$

$71-\mathrm{X}$

$31-1$
C Carex flava

C Carex distans

C. Carex verna

3-IV

$1-I I$

1-I

\section{Ostale biljke}

C Alectorolophus spec. $\quad 985-\mathrm{X}$

A Thymus serpyllum 954-X

C Leucanthemum vulgare 877-X

C Centaurea jacea 782-X

$B$. Stellaria graminea $611-\mathrm{X}$

A Leontodon autumnalis $481-\mathrm{rX}$

C Scabiosa agrestis

D Ranunculus acer

A Achillea millefollum

A Plantago lanceolata

A Veronica chamaedrys

B Moenchia mantica

A Brunella vulgaris

A Crepis biennis

B Daucus carota

D Euphorbia verrucosa

D Linum catharticum

A Polygala vulgaris

B Cerastium glomeratum

$409-1 X$

$347-\mathrm{X}$

$333-\mathrm{X}$

315-IX

239-VIII

236-VI

233-IX

223-IX

157-IV

113-IV

97-VI

70 - IX

69-IX

69-VIII

67-VI

66-VII

65-IV

$36-\mathrm{VI}$

$36-\mathrm{VI}$

$35-\mathrm{V}$

$34-I V$

34-IV

34-III

32-II

31-I

31-1

31-I.

$31-1$

7-VII

6-VII

5-VI

5-VI

5-VI

...5-VI 


\begin{tabular}{|c|c|c|c|c|c|}
\hline 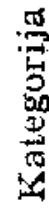 & Vrste bilja & $\begin{array}{l}\text { Pokrovnost } \\
\text { i stepen } \\
\text { prisutnosti }\end{array}$ & 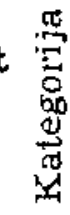 & $\dot{\text { Vrsta bilja }}$ & $\begin{array}{l}\text { Pokrovnost } \\
\text { i stepen } \\
\text { prisutnosti }\end{array}$ \\
\hline & Ostale biljke: & & $\stackrel{D}{D}$ & $\begin{array}{l}\text { Sambucus racemosus } \\
\text { Pteridium aquilinum }\end{array}$ & $1-I$ \\
\hline C & Rumex acetosella & $4-V$ & $D$ & Verbascum & $1-\mathrm{I}$ \\
\hline $\mathrm{C}$ & Hieracium pilosella & $4-V$ & C & Peucedanum & \\
\hline $\mathrm{C}$ & Lychnis flos cuculi & 3-IV & & oreoselinum & 1-I \\
\hline $\mathrm{C}$ & Phyteuma nigra & $3-I V$ & $\mathrm{~B}$ & Hypochoeris maculata & $1-\mathrm{I}$ \\
\hline A & Leontodon hispidus & 3-III & $\mathrm{C}$ & Stachys betonica & $1-I$ \\
\hline $\mathbf{C}$ & Hieracium florentinum & 3-III & $\mathrm{D}$ & Aquilegia vulgaris & $1-\mathrm{I}$ \\
\hline C & Veronica serpyltifolia & $3-I I I$ & $\mathrm{C}$ & Lappa maior & $1-1$ \\
\hline $\mathrm{C}$ & Salvia pratensis & 3-III & $\mathrm{C}$ & Cirsium acaule & $1-I$ \\
\hline $\mathrm{C}$ & Galium mollugo & $3-I I I$ & $\mathrm{D}$ & Polygonatum officinale & $1-I$ \\
\hline B & Campanula patula & $2-$ II & $\mathrm{B}$ & Fllipendula hexapetala & $1-\bar{I}$ \\
\hline $\mathrm{C}$ & Ajuga reptans & $2-I I$ & $\mathbf{B}$ & Plantago carinata & $1-I$. \\
\hline A & Pimpinella & $2-I I$ & A. & Euphrasia spec. & $1-I$ \\
\hline C & Allium spec. & $2-I I$ & $\mathrm{C}$ & Rumex crispus & $1 .-1$ \\
\hline $\mathrm{C}$ & Anthriscus spec. & I-I & $\mathbf{B}$ & Primula columnae & $1-I$ \\
\hline A & Convolvulus arvensis & $1-r$ & A & Galitum crticiatum & $1-I$ \\
\hline C & Plantago maior & I-I & c & Potentilla alba & 1. \\
\hline C & Gnaphalium silvaticum & $1-\mathrm{I}$ & $\mathrm{C}$ & Serratula lycopifolia & $1-I$ \\
\hline
\end{tabular}

U našoj tabeli broj I prikazana je pokrovna vrijednost vrsta u biljnoj zajednici Agrostis vulgaris, gdje se najvećom vrijednošcu ističu trave. Prema tabeli koja je izgrađena na osovu 16 florističkih, snimaka sa različitih lokaliteta u Gorskom Kotaru zastupljeni su: trave sa 32 vrste, saševi sa 5 vrsta, leguminoze 13 vrsta, a ostale biljke, koje pripadaju ostalim porodicama sa 140 vrsta. Trave imaju najveću prosječnu pokrovnost koja se kreće od 13.362-13.254, zatim dolaze ostale zeljaste biljke sa pokrovnošću od 8.313-7.602, leguminoze se kreću od 2.345 do 2.302, a najmanjom pokrovnošću od $107-71$ ističu se šaševi.

\section{Pokrovnost svih biljaka po stepenu stalnosti}

\begin{tabular}{rlrrr}
\hline $\begin{array}{l}\text { Red. } \\
\text { broj }\end{array}$ & \multicolumn{1}{c}{ Gr upe } & $\begin{array}{r}\text { Broj } \\
\text { vrsta }\end{array}$ & $\begin{array}{c}\text { Pokrovna } \\
\text { vrijednost }\end{array}$ & Procenat \\
\hline 1 & Trave & 32 & 13362 & 55,40 \\
2 & Leguminoze & 13 & 2345 & 9,72 \\
3 & Saševi & 5 & 107 & 0,44 \\
4 & Ostale zeljaste biljke & 140 & 8313 & 34,45 \\
\cline { 2 - 5 } & & 190 & 24127 & 100
\end{tabular}

\section{Pokrovnost biljaka $u$ višem stepenu stalnosti izražena u procentima (iznad 50\% - VI)}

Trave

Leguminoze

Sasevi

Ostale zeljaste biljke
13254 preracunato $u \%$ iznosi 57 2302

71

7602

$\begin{array}{ll}" \% & 0 \\ " \% & " \\ & \%\end{array}$

9,94

0,30 
Pokrovna vrijednost daje nam jasnu sliku o važnosti pojedine vrsteili cijelog skupa u samoj zajednici. Ona je ad velikog praktičnog značenja pri sastavljanju travnih smjesa za asocijaciju Agrostidetum vulea-

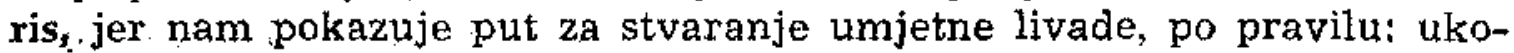
liko je neka biljka zastupljena većom polkrovnom vrijednošcu, a dobrog je kvaliteta, treba joj i u travnoj smjesi za dotično područje dati veći procenat.

\section{Određivanje množine pojedinih vrsta biljaka vaganjem svježe krme}

Rezultate o množini pojedinih vrsta biljaka zastupljenih u asocijaciji Agrostidetum dobili smo vaganjem. $U$ tu svrhu odabrana je tipična sastojina asocijacije Agrostidetum vulgaris i s nje je polkošena površina od $1 \mathrm{~m}^{2}$. Izvagana je ukupna količjna zelene mase i zatim su odvojene pojedine vrste i izvagane.

Uzorak zelene mase iz tabele broj 1 uzet na livadi sa $1 \mathrm{~m}^{2}$ iznosio je $0,8783 \mathrm{~kg}$. Izdvajanjem pojediníh vrsta u uzorki utvrđena je težina pojedinih skupina.

I. Dobre livadne trave:

\begin{tabular}{|c|c|}
\hline 1. Agrostis vulgaris & 115,0 \\
\hline 2. Festuca rubra & 93,0 \\
\hline 3. Dactylis glomerata & 22,0 \\
\hline 4. Cynosurus cristatus & 9,0 \\
\hline 5. Anthoxanthum odoratum & 8,0 \\
\hline 6. Briza media & 2,0 \\
\hline 7. Holcus lanatus & 2,0 \\
\hline
\end{tabular}

Ir. Leguminoze:

1. Trifolium pratense $\quad 67,0 \mathrm{gr}$.

IrI. Ostale korisne ili dobre biljke:

1. Achillea millefolium $\quad 42,0 \mathrm{gr}$.

2. Plantago Ianceolata

3. Brunella vulgaris

4. Taraxacum officinale

5. Stellaria graminea

6. Veronica Teucrium

7. Moenthia mantica

8. Daucus carota

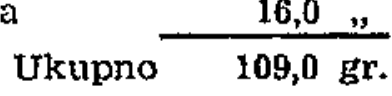

15,0 ,

15,0 ,

$12,0 "$

3,0 ",

4,5,

1,5 "
IV. Saševi:

I. Lusula campestris 0, (u tragovima)

V. Bezvrijedno i po zdravlje stoke škodljive biljke:

1. Ranunculus acer

2. Chrysanthemum $32,5 \mathrm{gr}$.

3. Rumex acetosa 3,0 "

4. Scabiosa agrestis $\quad 4,0 "$

5. Allium spec. $\quad 3,0$,

6. Alectorolophus .. . 1,0"

7. Orchis 0,3 ,

8. Althaea

9. Centaurea jacea

1,5,

Ukupno

$\frac{222,0 "}{271,3 \mathrm{gr} .}$

VI. Razne trave i nedeterminirani. dijelovi 168,0 grama

VII. Razne zeljaste biljke i dijelovi 12,0 grama

Ukupna težina svih skupina iznosi $0,8783 \mathrm{~kg}$.

Izraženo u procentima pojedinih grupa iznosi:

Trave $47,77 \%$,

Leguminoze $7,6 \%$,

Zeljaste biljke $44,63 \%$.

\section{Botanizka i težinska analiza sijena asocijacijskog tipa Agrostidetum}

Uzorak sijena uzet sa livade na Bijelim Vodicama u tabeli br. 1 . Izvagani uzorak sijena iznosio je 100 grama. 
Vrste zastupljene $u$ uzorku i težina pojedinih skupina:

I. Dobre livadne trave:

1. Agrostis vulgaris

$37,54 \mathrm{gr}$.

2. Cynosurus cristatus

3. Phleum pratense

4. Trisetum flavescens

5. Festuca rubra

6. Holeus lanatus

7. Anthoxanthum odoratum

8. Lolium perenne

9. Pou trivialis

10. Bromus racemosus
10,92 ,

9,12 ,

5,34 "

4,28

2,36

2,12 ,

0,22 ,"

0,20 ,

$1,78 \ldots$

$73,88 \mathrm{gr}$.
II. Leguminoxe:

1. Trifolium pratense

$6,48 \mathrm{gr}$.

III. Ostale korisne ili dobre biljke

1. Plantago lanceolata $3,18 \mathrm{~g}$ :

2. Taraxacum officinale 2,22 "

3. Stellaria graminea

Saševi:

1. Carex flava

$\frac{1,80 "}{7,20 \mathrm{gm} .}$

$0,10 \mathrm{gr}$.

V. Bezvrijedne $i$ po zdravlje stoke škodljive biljke:

1. Silene vulgaris

2. Rhynanthus maior

3. Centaurea jacea

$2,98 \mathrm{gr}$.

2,26

$\frac{0,30 \%}{5,54 \mathrm{gr} .}$

VI. Trine

$6,80 \mathrm{gr}$.

Botanička kategorizacija sijena prema krmnoj vrijednosti:

\begin{tabular}{clccc}
\hline $\begin{array}{c}\text { Red. } \\
\text { broj }\end{array}$ & \multicolumn{1}{c}{ Gr u pe } & $\begin{array}{c}\text { Težina u } \\
\text { gramima }\end{array}$ & Procenat & Klasa \\
\hline 1 & Dobre livadne trave & 73,88 & & \\
2 & Leguminoze & 6,48 & 87,56 & \\
3 & Ostale korisne ili dobre biljke & 7,20 & & \\
4 & Kisele (Sasevi) ili rdave trave & 0,10 & \\
5 & Bezvrijedne 1 po zdravije & & \\
6 & stoke skodijive biljke & 5,54 & 12,44 \\
\hline
\end{tabular}

Uzorak sijena uzet sa livade na Bijelim Vodicama $u$ tabeli br. 3. Izvagani uzorak sijena iznosio je 100 grama.

Vrste zastupljene. u uzorku i težina pojedinih skupina:

I. Dobre livadne trave:

1. Agrostis vulgaris

2. Bromus racemosus

3. Dactylis glomerata

4. Lolium perenne

5. Festuca pratensis

6. Festuca rubua

7. Anthoxanthum odoratum

8. Holcus lanatus

9. Cymosurus cristatus

10. Poa trivialis

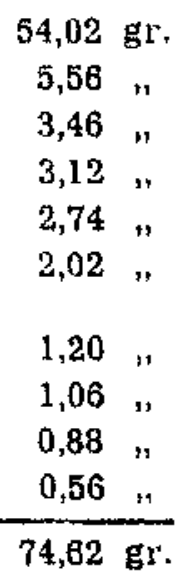

\section{Leguminoze:}

1. Trifolium repens

2. Trifolium campestre

3. Lotus corniculatus

4. Trifolium pratense
III. Ostale korisne ill dobre biljke:

1. Brunella vulgaris

2. Stellaria graminea

3. Plantago lanceolata

4. Thymus serpyllum

5. Taraxacum officinale

6. Carum carvi

7. Achillea millefolium

Saševi:

$1,58 \mathrm{gr}$.

2,38 ,

1,60 ,

0,70

0,20 ,"

$0,26,11$

0,34 .11.

$7,06 \mathrm{gr}$.

1. Luzula campestris

2. Rumex acetosella

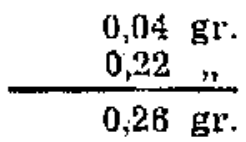

V. Bezvrijedne 1 po zdravlje stoke skodljive biljke:

1. Chysanthemum leucanthemum

2. Rhynanthus maior

3. Centaurea jacea

4. Scablosa agrestls

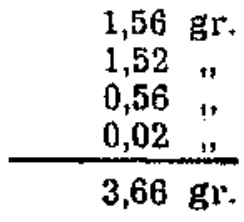

VI. Trine:

$5.70 \mathrm{gr}$. 
Botanička kategorizacija sijena prema krmnoj vrijednosti:

\begin{tabular}{clccc}
\hline $\begin{array}{c}\text { Red. } \\
\text { broj }\end{array}$ & \multicolumn{1}{c}{ Gr u pe } & $\begin{array}{c}\text { Težina } u \\
\text { gramima }\end{array}$ & Procenat & Klasa \\
\hline 1 & Dobre livadine trave & 74,62 & \\
2 & Leguminoze & 8,70 & 90,38 & \\
3 & Ostale korisne ili dobte biljke & 7,06 & \\
4 & Kisele (šaševi) ili rdave trave & 0,26 & \\
5 & Bezvrijedne i po zdravlje & & \\
& stoke šlkodljive biljke & 3,66 & 9,62 \\
6 & Trine & $\mathbf{5 , 7 0}$ & \\
\hline
\end{tabular}

Uzorak sijena uzet sa livade na Bijelim Vodicama u tabeli br. 4 Izvagani uzorak sijena iznosio je 100 grama.

Vrste zastupljene u uzorku i težina pojedinih skupina:

\section{Dobre livadne trave:}

1. Agrostis vulgaris

2. Lolium perenne

3. Bromus racemosus

4. Cynosurus cristatus

5. Holcus lanatus

B. Trisetum flavescens

7. Poa trivialis

8. Dactylis glomerata

9. Anthoxanthum odoratum

$\frac{0,44,}{48,28 \mathrm{gr} .}$

Ix. Leguminoze:

1. Trifolium repens

2. Medicago lupulina

3. Trifolium campestre

\begin{tabular}{l}
$3,64 \mathrm{gr}$. \\
$0,56 \%$ \\
$0,04 \%$ \\
\hline $4,24 \mathrm{gr}$.
\end{tabular}

3,78 .

2,76 ,

2,16 ,

1,32 ,

1,28 ,
III. Ostale korisne ili dobre biljke: 1. Plantago lanceolata

2. Stellaria graminea $4,24 \mathrm{gr}$.

3. Achillea millefolium

4. Taraxacum officinale

5. Dianthus armeria

6. Veronica officinale

7. Bellis perennis

4,50

$3,78 "$

$2,64 "$

2,24 ,"

IV. Saševi:

0,96

0,02

$18,38 \mathrm{gr}$.

V. Bezvrijedne i po zdravlje stoke

\section{škodljive biljke:}

1. Silene vulgaris

2. Genista sagittalis

3. Centauera jacea

4. Chrysanthemum leucanthemum

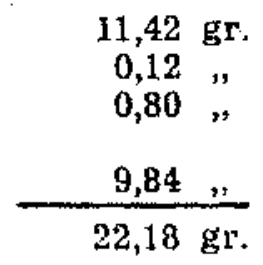

VI. Trine:

$6,82 \mathrm{gr}$.

Botanicka kategorizacija sijena prema krmnoj vrijednosti:

\begin{tabular}{|c|c|c|c|c|}
\hline $\begin{array}{l}\text { Red. } \\
\text { broj }\end{array}$ & $G \sim$ upe & $\begin{array}{l}\text { Tezina u } \\
\text { gramima }\end{array}$ & Procenat & Klașa \\
\hline 1 & Slatke livadne trave & 48,28 & & \\
\hline 2 & Leguminoze & 4,24 & 70,90 & II \\
\hline 3 & Ostale korisne ili dobre biljke & 18,38 & & \\
\hline 4 & Kisele (saševi) ill rdave trave & - & & . \\
\hline 5 & $\begin{array}{l}\text { Bezvrijedne i po zdravlje } \\
\text { stoke skodljive biljke }\end{array}$ & 22,18 & 29,10 & \\
\hline 6 & Trine & 6,92 & & \\
\hline
\end{tabular}




\section{UPOREOENJE REZULTATA PROCJENE I VAGANJA}

$\mathrm{U}$ botaničkim analizama istiłu se najvećom težinom trave $i$ to od 70,92-14,62 grama. Od trava po težini je najviše zastupljena Agrostis vulgaris od 37,54-54,02 grama, koja je karakteristična vrsta asocijacije Agrostidetum. Iza nje dolaze po težini Cynosurus cristatus, Phleum pratense, Trisetum flavescens, Festuca rubra, Dactylis glomerata, Lolium perenne, Bromus racemosus, Festuca pratensis, Anthoxanthum odoratum i Poa trivialis.

Od leguminoza najvećom težinom istič se Trifolium pratense sa 6,48 grama, zatim Trifolium repens 3,64 grama i Trifolium campestre 3,50 grama.

Od ostalih biljaka naročito se ističu Stellaria graminea $1,50-4,50$ grama, Plantago lanceolata $1,60-4,24$ grama, Silene vulgaris 2,98 grama, Chrysanthemum leucanthemum 1,56 grama i Centaurea jacea $0,30-0,56$ grama.

Tabela nam prema tome, daje ne samo uvid u botanički sastav asocijacije Agrostidetum vulgaris, nego i uvid u brojčane odnose pojedinih vrsta, osobito ako se uzme u obzir pokrovna vrijednost.

Kako tabela ujedinjuje veoma velik broj snimaka, koji se procje'nom brže dobijaju nego vaganjem, ona daje zanimljyivu sliku o sastavu sijena, a uporedena sa rezultatima vaganja svježe klme i suvog sijena pruža mogućńost potpunijeg iskorišćavanja podataka za taj tip livade. Stoga je potrebno da vaganju svježe krme i suvog sijena prethode floristička istraživanja vegetacijskog pokrivača $i$ to $s$ obzirom na prisutnost i pokrovnost vrsta $u$ plohi.

\section{5 - Asocijacija Arrhenatheretum elatioris}

Dolinske livade Arrhenatheretum elatioris i Cynosuretum cristati, koje je kod nas vrlo iscrpno obradio $S t j e p a n$ Horvatic, pripadaju među naše najbolje livade, jer daju odlično sijeno i otavu. Ove bujne livade nalaze se na blagim nagibima i ravnim površinama dolina. za vrijeme jakih kiša i poplava povremeno su poplavljivane te imaju dovoljno vlage, u izvjesnim slučajevima i preobilno. Povremene kratke poplave donose mineralne $\mathfrak{i}$ humusne materije sa višił položaja, sto. omogućuje bujan razvitak trava, leguminoza i zeljastih biljaka.

Livade francuskog ljulja održaće se na svježim dobro dubrenim i dobro njegovanim polozajima, dok na suvim i nedubrenim livadama francuskog ljulja prelazi u livadu asocijacijskog tipa Bromus erectus Plantago media.

U asocijaciji Arrhenatheretum elatioris isticu se od trava Arrhenatherum elatius, Trisetum flavescens, Dactylis glomerata, Poa pratensis, Poa trivialis, Festuca pratensis i Festuca rubra. Od leguminoza Trifolium pratense, Trifolium repens, Trifolium patens i Lotus corniculatus. Od zeljastih biljaka Tragopogon pratensis, Knautia arvensis, Pastinaca sativa, Tanaxacum officinale, Crepis biennis, Chrysanthemum leucanthemum, Daucus carota, Salvia pratensis, Cichorium inthybus.

U podruçju Gorskog Kotara ovaj tip nije mnogo raširen i nije naj-tipičnije građen, ali ipak zauzima značajna staništa uz naselja i dajeveliku kolixinu sijena. 


\section{Grupacija biljaka u asocijaciji Arrhenatheretum elatioris po kategorijama, prosječnoj pokrovnosti i stepenu prisutnosti}

\begin{tabular}{|c|c|c|c|c|}
\hline 愛 & Vrsta bilja & $\begin{array}{cc}\text { Pokrovnost } & \text { 焉 } \\
\text { i stepen } \\
\text { piisutnosti }\end{array}$ & Vrsta bilja & $\begin{array}{l}\text { Pokiovnost } \\
\text { i stepen } \\
\text { prisutnosti }\end{array}$ \\
\hline
\end{tabular}

\section{Trave:}
A Arrhenatherum elatius
A Trisetum, flavescens
B Folcus lanatus
B Anthoxanthum odoratum

A Dactylis glomerata

A Poa pratensis

B Briza media

A Festuca pratensis

A Poa bulbosa

A Festuca rubra

B Bromus racemosus

A Cynosurus cristatus

C Bromus hordeaceus

A Phleum pratense

A Lolium perenne

A Agrostis alba

A Poa trivialis

A Agropyrum repens

\section{Leguminoze:}
A Trifolium pratense
A Trifollum patens
C Ononis hixcina
A Medicago lupulina
A Lotus cornicutatus
A Trifolium campestre
A Medicago falcata
B Anthyllis vulneraria
A Trifolium repens
A Vicia cracca
A Lathyrus pratensis

\section{Saševi:}

D Equisetum arvense

C Carex glauca

D Equisetum palustre

C Carex hirta

C Carex ,vulpina

C Carex distans

C Luzula campestris

\section{Ostale biljke:}

B Daucus carota

\section{Chrysanthemum} leucanthemum
$2401-X$

1450-VII 718-VIII

335-VI

203-VII

191-III

136-VI

$135-\mathrm{V}$

117-I

104-VI

101-IV

$69-I V$

37-IV

2-II.

$1-$ II

$1-71$

1-II

1-II

$833-\mathrm{X}$

835-VI

653-VI

374-III

270-IX

268-1V

$70-\mathrm{V}$

35-III

3-III

3-III

1-II

1-II

485-VI

119-III

117-I

35-III

2-II

$1-I I$

I-II
B Pastinaca sativa

A Plantago lanceolata

C Centaurea jacea v. pectinata

C Galium mollugo

C Sedum boloniense

A Crepis biennis

A Leontodon hispidus

A Brunella vulgaris

D Ranunculus acer

C Potentilla reptans

C Salvia patens

$B$ Knautia arvensis

A Leontodon autumnale

A Achillea millefolium

A Galium verum

C Rumex acetosa

B Saturea vulgaris

A Carum carvi

C Centaurea jacea ssp. jacea

A Thymus chamaedrys

B Plantago media

A Taraxacum officinale

$B$ Moenchia mantica

C Centaurea macroptilon

C Alectrolophus maior i

A. minor

$B$ Cichorium inthybus

C Picris hieracioides

A Pimpinella maior

C Stachys officinalis

C Scabiosa agrestis

C Cerastium caespitosum

B Tragopogon pratensis

A Convolvulus arvensis

C Symphytum officinale

D Colchicum autumnale

A Stellaria graminea

C Myosotis arvensis

C Allium oleraceum

A Hypochoeris radicata

A Polygala vulgaris

D Euphorbia virgata

C Rumex crispus

C Veronica arvensis

D Hypericum perforatum

C Cirsium canum

$1168-\mathrm{rX}$

C Ajuga reptans

B Clrsium arvense

$850-\mathrm{X}$
635-VIII

$453-X$

418-VI

386-IX

$384-V$

$380-\mathrm{X}$

370-VIII

$355-\mathrm{X}$

353-VIII

351-III

268-IV

267-II

204-VIII

201-VI

$187-\mathrm{V}$

151-II

151-II

150-II

$135-\mathrm{V}$

134-IV

119 -1II

117-I

101-III

$71-\mathrm{VI}$

71-VI

67-II

61-II

61-II

61-II

38-VI

$37-\mathrm{V}$

$37-V$

35-III

35-II

35-I

3-III

2-II

2-II

2-II

2-II

2-II

2-II

2-II

2-II

2-II

2-II

1-II.

1-II 


\begin{tabular}{|c|c|c|c|c|c|}
\hline 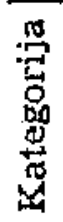 & Vrste bilja & $\begin{array}{l}\text { Pokrownost } \\
\text { i stepen } \\
\text { plisutnosti }\end{array}$ & 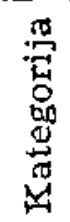 & Vrste bilja & $\begin{array}{l}\text { Pokrovnost } \\
\text { i stepen } \\
\text { prisutnosti }\end{array}$ \\
\hline $\begin{array}{l}C \\
A \\
D \\
C \\
C \\
C \\
C\end{array}$ & $\begin{array}{l}\text { Buphthalmum } \\
\text { salicifolium } \\
\text { Sanguisorba minor } \\
\text { Cuscuta epithymum } \\
\text { Senecio jacobea } \\
\text { Lythrum sallcaria } \\
\text { Linaria vulgaris } \\
\text { Lysimachia } \\
\text { nummularia } \\
\text { Ostale biljke: }\end{array}$ & $\begin{array}{l}1-I \\
1-I \\
1-I I \\
1-I I \\
1-I I \\
1-I I \\
1-I I\end{array}$ & $\begin{array}{l}\text { D } \\
\text { C } \\
\text { A } \\
\text { A } \\
\text { B } \\
\text { C } \\
\text { C } \\
\text { C } \\
\text { C }\end{array}$ & $\begin{array}{l}\text { Linum catharticum } \\
\text { Lychnis flos cuculi } \\
\text { Bellis perennis } \\
\text { Euphrasia } \\
\text { Rostkoviana } \\
\text { Filipenciula hexapetala } \\
\text { Heracleum } \\
\text { sphondylium } \\
\text { Orchis latifolius } \\
\text { Orobanche lutea } \\
\text { Orchis corjophorus }\end{array}$ & $\begin{array}{l}1-I I \\
1-I I \\
1-I I \\
1-I \\
1-I \\
1-I \\
1-I \\
1-I \\
1-I\end{array}$ \\
\hline $\begin{array}{l}\mathrm{B} \\
\mathrm{B}\end{array}$ & $\begin{array}{l}\text { Glechoma hederacea } \\
\text { Campanula patula }\end{array}$ & $1-$ II & & & \\
\hline
\end{tabular}

U prethodnoj tabeli prikazana je pokrovna vrijednost vrsta $u$ biljm noj zajednici Arrhenatheretum elatioris, gdje se sa najvecom vrijednošcu isticu zeljaste biljke.

Prema tabeli koja je izradena na osnovu 15 florističkih snimaka profesora $\mathrm{H}$ or vatic a sa razlicitih lokaliteta Hrvatske, zastupljene su trave sa 18 vrsta, leguminoze sa 12 vrsta, šaševi sa 7 vrsta, a ostale zeljaste biljke, koje pripadaju razlicitim porodicama sa 68 vrsta.

Pokrovnost biljaka po stepenu stalnosti

\begin{tabular}{rlrrr}
$\begin{array}{c}\text { Red. } \\
\text { broj }\end{array}$ & Gru p o & $\begin{array}{c}\text { Broj } \\
\text { vista }\end{array}$ & $\begin{array}{c}\text { Pokrovia } \\
\text { vrijednost }\end{array}$ & Procenat \\
\hline 1 & Trave & 18 & 6003 & 29,57 \\
2 & Leguminoze & 12 & 3346 & 16,48 \\
3 & Saševi & 7 & 760 & 3,74 \\
4 & Ostale zeljaste biljke & 68 & 10192 & 50,21 \\
\cline { 3 - 5 } & & 105 & 20301 & 100
\end{tabular}

Zeljaste biljke imaju najveću pokrovnost 10192 ili $50,21^{\circ} / 0$, zatim dolaze trave sa 6003 ili $29,57 \%$, leguminoze sa 3346 ili $16,48 \%$, dok su sasevi sa najmanjom pokrovnošcu 760 ili $3,74^{1} / \mathrm{o}^{\prime}$

Batanicka i težinska analiza sijena asocijacijskog tipa Arrhenatheretum elatioris

Uzorak sijena uzet sa livade prema Gornjem Jelenju sa torene povrŠine. Izvagani uzorak sijena je iznosio 100 grama. 
Vrste zastupljene u uzorku i težina pojedinih skupina:

I. Dobre livadne trave:
1. Avena elatior
2. Agrostis vulgaris
3. Festuca pratensis
4. Festuca rubra
5. Avenastrum pratense
6. Koeleria pyramidata
7. Briza media

1II. Ostale korisne ili dobre biljke:

1. Plantago media $\quad 3,84 \mathrm{gr}$.

2. Knautia arvensis 1,45 "

3. Filipendula hexapetala 0,27 ,

4. Helianthemum obscurum 0,06 ",

5. Veronica spec. $\quad 0,30, "$,

IV. \$aševi:

1. Luzula campestris

2. Carex pannicea

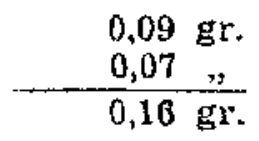

V. Bezvrijedne i po zdravlje stoke škodljive biljke:

\section{Leguminoze:}

1. Trifolium pratense

2. Trifolium repens

3. Lotus corniculatus

4. Medicago lupulina

$\begin{array}{r}4,40 \mathrm{gr} . \\ 0,51 " \\ 0,12 . \\ 0,58 . \\ \hline 5,61 \mathrm{gr} .\end{array}$

\section{Centaurea jacea}

1. Centaurea jacea $\quad 8,96 \mathrm{gl}^{\prime}$

2. Alectorolophus maior 1,00 "

3. Allium sper

4. Chrysanthemum leucanthemum

\section{$\frac{0,90 \%}{10,96 \mathrm{gr} \text {. }}$}

VI. Trine:

Botanička kategorizacija sijena prema krmnoj vrijednosti:

\begin{tabular}{clccc}
\hline $\begin{array}{c}\text { Red. } \\
\text { broj }\end{array}$ & \multicolumn{1}{c}{ Gr u p e } & $\begin{array}{c}\text { Tezina u } \\
\text { gramima }\end{array}$ & Procenat & Klasa \\
\hline I & Slatke livadne trave & 67,09 & & \\
2 & Leguminoze & 5,61 & 78,62 & I \\
3 & Ostale korisne i dobre biljke & 5,92 & & \\
4 & Kisele (šasevi) ili rdave trave & 0,16 & \\
5 & $\begin{array}{l}\text { Bezvijedne ili po zdravlje } \\
\text { stoke škodljive biljke }\end{array}$ & 10,96 & 21,38 \\
& Trine & 10,26 & & \\
\hline
\end{tabular}

\section{6 - Asocijacija Cynoșuretum cristati (livada krestaca)}

Livada krestaca raširena je na nižim vlažnim staništima sjev. Hrvatske i zaprema, kako kaže S. Horvat i ć, velike povrß̧ine. U Gorskom Kotaru ona zaprema srazmjerno male prostore u položitijem poplav่nom području gdje ima dosta vlage. Ako je uz to i nivo podzemne vode visok, razvija se treset ili močvarna vegetacija u kojoj se razvijaju razne vrste roda Carex, Juncus, Scirpus, Equisetum, Ranunculus i Deschampsia. $U$ vezi s minimalnim promjenama reljefa nalazi se cesto $u$ neposrednoj blizini druge zajednice kao Caricetum i Deschampsietum, ali najveće površine pokrịva ipak Cynosuretum.

Livade krestaca javłjaju se najčešće $u$ tri varijante: prva varijanta u kojoj prevladava travna vrsta Alopecurus pratensis sa pokrovnosću koja doseže do preko $80 \%$, dnuga varijanta u kojoj prevladavaju Festuca pratensis i Dactylis glomerata sa pokrovnosću do preko $40 \%$, i treća 
varijanta u kojoj prevladavaju Holcus lanatus, Agrostis vulgaris i Festuca rubra do $30 \%$.

Karakteristične virste biljne zajednice Cynosuretum existati jesu: Alopecurus atriculatus, Alopecurus pratensis, Ophioglossum vulgatum, Gaudinia fragilis, Cynosurus cristatus, Poa trivialis i Bromus racemosus. Neke od njih nisu nađene u Gorskom Kotaru (upor. Hor va ti ć). Pored trava zastupljene su u zajednici leguminoze i druge zeljaste biljke.

Prema iznesenom asocijacija Cynosuretum cristati pretstavlja veoma sočne i bujne livade koje daju obilne otkose, kako sijena tako i otave, ali se pojedine varijante (subasocijacije) očito razlikuju.

Naš snimak nije najtipičniji za ovu asocijaciju, naprotiv on pretstavlja najvlažniju subasocijaciju u kojoj je mnogo zastupljena preslica.

Grupacija biljaka $u$ asocijaciji Cynosuretum cristati typicum po kategorijama, prosječnoj pokrovnosti i stepenu prisutnosti

\begin{tabular}{|c|c|c|c|c|}
\hline 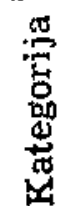 & Vrsta bilja & $\begin{array}{c}\text { Pokrovnost } \\
\text { i stepen } \\
\text { prisutnosti }\end{array}$ & Vrste bilja & $\begin{array}{l}\text { Pokrovnost } \\
\text { i stepen } \\
\text { prisutnosti }\end{array}$ \\
\hline
\end{tabular}

Trave:

A Cynosurus cristatus

A Poa trivialis

A Agrostis alba

A Alopecurus pratensis

B Anthoxanthum odoratum

A Festuca pratensis

$B$ Bromus racemosus

$B$ Holcus lanatus

A Festuca rubra

A Phleum pratense

B Briza media

A Alopecurus utriculatus

A Trisetum flavescens

A Lolium perenne

A Dastyilis glomerata

A Arrhenatherum elatior.

C Deschampsta caespitosa

A Poa pratensis

C Bromus hordeaceus

\section{Leguminoze:}

A Trifolium patens

A Trifolium pratense

C Ononis hircina

A Lotus corniculatus ssp. eucorniculatus

A Lotus corniculatus

- ssp. tenuifolius

A Medicago Iupulina

A Vicia cracca

2

\begin{tabular}{|c|c|c|c|}
\hline $\begin{array}{l}295-X \\
615-V I I I \\
525-V I I \\
318-I I\end{array}$ & & $\begin{array}{l}\text { Trifolium repens } \\
\text { Lathyrus pratensis }\end{array}$ & $\begin{array}{l}3-I I I \\
2-I I\end{array}$ \\
\hline $\begin{array}{l}296-V \\
140-V I I \\
111-V I I I \\
94-V \\
91-I I \\
50-V I \\
47-I I I \\
46-I I \\
45-I \\
4-I V \\
2-I I \\
1-I\end{array}$ & $\begin{array}{l}C \\
C \\
C \\
C \\
C \\
D \\
C \\
C \\
C\end{array}$ & $\begin{array}{l}\text { Calex pallescens } \\
\text { Carex leporina } \\
\text { Juncus effusus } \\
\text { Carex distans } \\
\text { Carex hirta } \\
\text { Equisetum arvense } \\
\text { Juncus compressus } \\
\text { Carex panicea } \\
\text { Carex muricata }\end{array}$ & $\begin{array}{l}48-I V \\
47-I I I \\
45-I \\
5-V \\
5-V I \\
2-I I \\
1-I \\
1-I \\
1-I\end{array}$ \\
\hline $\begin{array}{l}1-I \\
1-I \\
I-I\end{array}$ & $\begin{array}{l}\mathrm{C} \\
\mathrm{D} \\
\mathrm{A} \\
\mathrm{C}\end{array}$ & $\begin{array}{l}\text { Centaurea jacea var. } \\
\text { pectinata } \\
\text { Gandinia fragills } \\
\text { Ranunculus ace. } \\
\text { Plantago lanceolata } \\
\text { Chrysanthemum } \\
\text { leucanthemum }\end{array}$ & $\begin{array}{l}752-\text { VII } \\
659-I I I \\
594-X \\
594-X \\
434-I X\end{array}$ \\
\hline $\begin{array}{l}1614-X \\
818-I X \\
319-I I I\end{array}$ & $\begin{array}{l}\mathrm{C} \\
\mathrm{B} \\
\mathrm{B} \\
\mathrm{A}\end{array}$ & $\begin{array}{l}\text { Stachys officinalis } \\
\text { Daucus carota } \\
\text { Galium palustre } \\
\text { Leontodon hispidus }\end{array}$ & $\begin{array}{l}388-\text { IV } \\
319-\text { IV } \\
319-\text { IIL } \\
319-\text { III }\end{array}$ \\
\hline $\begin{array}{l}206-I V \\
184-\mathrm{VI} \\
159-\mathrm{I} \\
47-\mathrm{III}\end{array}$ & $\begin{array}{c}\mathbf{C} \\
\mathbf{A} \\
\mathbf{A}\end{array}$ & $\begin{array}{l}\text { Potentilla reptans } \\
\text { Galium verum } \\
\text { Leontodon autumnalis } \\
\text { Brunella vulgaris } \\
\text { Alectrolophus maior }\end{array}$ & $\begin{array}{l}299-V I I I \\
297-V I \\
252-V I \\
230-V I I I \\
159-1\end{array}$ \\
\hline
\end{tabular}

3-III

(15-

$525-V I I$

318-II

296-V

$111-$ VIII

34-V

91-II

$50-\mathrm{VI}$

47-III

$-I 1$

$4-I V$

2-II

$1-1$

pectinata

C Candinia fragilis

D Ranunculus ace

A Plantago lanceolata

Chrysanthemum

leucanthemum

C Stachys officinalis

$B$ Daucus carota

B Galium palustre

eontodon hispidus

A Galium verum

47-III
A Brunella vulgaris

C Alectrolophus maior
47-III

$45-I$

5-VI

2-II

1-I

1-I

659-III

$594-\mathrm{X}$

434-IX

388-IV

319-III

319-III

297-VI

159-1 


\begin{tabular}{|c|c|c|c|c|c|}
\hline 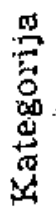 & Vusta bilja & $\begin{array}{l}\text { Pokrovnost } \\
\text { i stepen } \\
\text { prisutnosti }\end{array}$ & 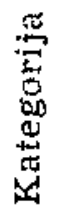 & Vrsta bilja & $\begin{array}{l}\text { Pokrovnost } \\
\text { i stepen } \\
\text { prisutnosti }\end{array}$ \\
\hline
\end{tabular}

D Colchicum autumnale i A. minor

D Ranunculus repens

A Crepis biennis

A Carum carvi

C Senecio jacobea

B Cichorium Inthybus

C Rumex acetosa

A Taraxacum officinale

C Oenanthe media

C Lychnis flos cuculi

C Gratiola officinalis

A Bellis perennis

C Allium olleraceum

A Achillea millefolium

A Alchemilla vulgaris

D Lilium bulbiferum

C Centaurea jacea

A Convolvulus arvensis

C Ophloglossum

vultagum

D Ranunculus flammula

D Ranunculus sardous

\begin{tabular}{|c|c|c|c|}
\hline & B & Cerastium & \\
\hline 95-VII & $C$ & caespitosum & $a^{2-I I}$ \\
\hline 93-IV & A. & Hypochoeris radicata & $2-i 1$ \\
\hline $9 I-I I$ & $\mathrm{~B}$ & Veronica arvensis & $2-I T$ \\
\hline $50-V$ & $\mathrm{~B}$ & Polygala vulgaris & $2,1 I$ \\
\hline $50-\mathrm{VI}$ & B & Veronica serpyllifolia & 2-II \\
\hline $49-V$ & C & Centaurea pulchellum & $2-I I$ \\
\hline $48-I V$ & $\mathrm{C}$ & Dianthus armeria & $2-I I$ \\
\hline $47-I V$ & A & Taraxacum palustre & 2-II \\
\hline $47-$ III & $\mathrm{C}$ & Oenanthe fistulosa & $I-I$ \\
\hline $47-I I I$ & $\mathrm{~B}$ & Knautia arvensis & $1-I$ \\
\hline $46-I I$ & C & Scabiosa agrestis & $1-I$ \\
\hline $46-$ III & D & Cardamine pratensis & $1-I$ \\
\hline $45-I$ & A & Thymus chamaedrys & I-I \\
\hline $45-\mathrm{I}$ & $\mathbf{D}$ & Verbascum blattaria & $1-I$ \\
\hline $45-I$ & $\mathrm{D}$ & Ranunculus bulbosus & $1- \pm$ \\
\hline $45-I I$ & $\mathrm{C}$ & Cirsium canum & $1+1$ \\
\hline $5-I$ & $\mathrm{D}$ & Cuscuta epithymum & $1-I$ \\
\hline & $\mathrm{B}$ & Filipendula hexapetala & $1-I$ \\
\hline $5-V$ & $\mathrm{C}$ & Lysimachia & $1-I$ \\
\hline $4-I V$ & & nummularia & $\mathbf{I}-\bar{I}$ \\
\hline 2-II & C & Lythrum salicaria & $1-I$ \\
\hline
\end{tabular}

U asocijaciji Cynosuretum cristati typicum iz prethodne tabele koja je izgrađena na osnovu 11 floristiðkih snimaka iz tabele Horvatića sa razlicitih lokaliteta Hrvatske, zastupljene su trave sa 19 vrsta, leguminoze sa 9 vrsta, šševi sa 9 vrsta, a ostale biljke, koje pripadaju razlixitim porodicama sa 57 vrsta.

\section{Pokrovnost biljaka po stepenu stalnosti}

\begin{tabular}{llrrr}
\hline $\begin{array}{l}\text { Red. } \\
\text { broj }\end{array}$ & $\begin{array}{c}\text { Brof } \\
\text { vrsta }\end{array}$ & $\begin{array}{c}\text { Pokrovna } \\
\text { vrijednost }\end{array}$ & Procenat \\
\hline 1 Trave & 19 & 4727 & $\mathbf{3 1 , 7 7}$ \\
2 Leguminoze & 9 & 3352 & $\mathbf{2 2 , 5 3}$ \\
3 Saševi & 9 & 156 & 1,05 \\
4 Ostale zeljaste biljke & 57 & 6645 & 44,65 \\
\hline & 94 & 14880 & 100
\end{tabular}

Najveću pokrovnost imaju zeljaste biljke sa 6645 ili $44,65 \%$ zatim dolaze trave sa 4727 ili $31,77 \%$, leguminoze sa 3352 ili $22,53 \%$, dak su Xaševi sa najmanjam pokrovnošcu 156 ili $1,05 \%$. 


\section{Botanička i težinska analiza sijena asocijacijskog tipa Cynosuretum cristati}

Uzorak sijena uzet je sa livade na Mrzlim Vodicama. Izvagani uzorak sijena iznosio je 100 grama.

Vrste zastupljene u uzorku i težina pojedinih skupina:

I. Dobre livalske trave:

1. Agrostis vulgaris

2. Cynosurus cristatus

3. Dactylis glomerata

4. Festuca pratensis

5. Phleum pratense

6. Trisetum flavescens

7. Bromus racemosus

8. Anthoxanthum odoratum

9. Holcus lanatus

10. Poa pratensis

III. Ostale Korisne ili dobre biljke:

1. Alchemilla vulgaris $\quad 0.06 \mathrm{gr}^{*}$

2. Brunella vulgaris 1,86,

3. Filipendula hexapetala 1,24 ,"

4. Plantago lanceolata 0,32 ,

5. Euphrasia spec. 0,30"

6. Veronica serpyllifolia $0.10 "$

IV. Saševi:

$3,88 \mathrm{gr}$

1. Carex vulpina

$1,78 \mathrm{gr}$

v. Bezvrijedne ili po zdravljo stoke skodljive biljke:

1. Colchicum autumnale $15,64 \mathrm{gr}^{\prime}$

2. Cardamine pratensis 3,56 ,

3. Silene vulgaris 1,20 ,

4. Equisetum palustre $\quad \mathbf{0 , 6 6}$

5. Ranunculus acer

0,04

$21,10 \mathrm{gr}$

VI. Trine:

$5,04 \mathrm{gr}^{2}$

Botanička kategorizacija sijena prema krmnoj vrijednosti:

\begin{tabular}{|c|c|c|c|c|}
\hline $\begin{array}{l}\text { Red. } \\
\text { broj }\end{array}$ & Grupe & Težina u gr. & Procenat & Klasa \\
\hline 1. & Dobre trave & 62,62 & & \\
\hline 2. & Leguminoze & 6,00 & 72,10 & II \\
\hline 8. & Ostale korisne ili dobre biljke & 3,88 & & \\
\hline 4. & Kisele (šasevi) ili raave trave & 1,76 & & \\
\hline 5. & $\begin{array}{l}\text { Bezvrijedne i po zdravlje skodljive } \\
\text { biljke }\end{array}$ & 21,10 & 27,90 & \\
\hline 6. & Trine & 5,04 & & \\
\hline
\end{tabular}

\section{PRINOS ZELENE KRME I SIJENA U POJEDINIM ASOCIJACIJAMA}

Pojedine biljne asocijacije vidno se razlikuju po prinosu zelene mase i sijena na jedinici površine. $\mathrm{Da}$ dobijemo približnu sliku o količni krme, koju daju pojedini tipovi, sabrali smo uzorke na vecem broju povrsina koje su pripadale razlixitim asocijacijama. Kod odabiranja po vršina iłli smo za tim da saberemo uzorke iz floristickih i ekoloskin 
najtipičnijih sastojina bez obzira na momentalne uticaje, npr. dubrenje; kojima ce trebati obratití još posebnu pažnju. Ova istraživanja vršena su nažalost samo u jednoj sezoni, ali u prosječno umjereno vlažnoj godini, a broj uzoraka takode je dosta malen, ali su prigodna opažanja na velikom broju površina pokazala izvjesna podudaranja.

Mi smo sabrali npr. uzorke iz 6 površina asocijacije Agrostidetum vulgaris, koje su floristički vrlo jasno okarakterisane, ali se razlikuju $u$ obradi: jedne su jače đubrene, druge manje, pa kod njih prinos zelene krme varira u znatnoj mjeri. Bilo nam je stalo do toga da upoznamo razlike $i \mathrm{u}$ tom pravcu. Odakle potiču velike razlike u količini sijena prvog $i$ šestog uzorka? Prvi uzorak pretstavlja već krajnju degradaciju, osiromašenje asocijacije Agrostidetum vulgaris, koja se približuje već granici asooijacije Nardetum strictae, dok kod šestog uzorka imamo najveći prinos, što je rezultat optimalnih uslova za razvoj ovog tipa.

I uzorci sabrani $u$ asocijaciji Nardetum strictae razlikuju se zbog istih uzroka. Nardetum na Glocevcu bio je prije desetak godina obilno gnojen, on sadrži neke elemente Agrostidetuma i pokazuje znatno veći prinos od tipičnih površina iz Bijele Vodice, koja pretstavlja prosjek tipičnog Nardetuma (upor. 13,14).

Pod uticajem obrade mijenja se dakle prinos zelene krme i sijena unutar jstog tipa, pa treba proučiti veći broj uzoraka da dobijemo veći prosjek za svaku zajednicu. Naprotiv, vidimo da su kod prirodnih livada, kod kojih je uticaj čovjeka znatno manji, i razlike $u$ uzorcima mnogo manje, cesto upravo neznatne, što najljepše pokazuje subasocijacija Mesobrometum (upor. uzorak 8 i 9 ).

Prema priloženoj tabeli izračunati su prosječni prinosi u asocijaciji Agrostis vulgaris i iznose $14,059 \mathrm{~kg}$ zelene mase ili $5,044 \mathrm{~kg}$ sijena. Kod brdskih livada asocijacijskog tipa Bromus erectus - Plantago media dobijeni su slijedeći prosječni prinosi po ha: u subasocijacijskom (vlažnijem) tipu Mesobrometum $9.403 \mathrm{~kg}$ zelene mase ili $3.550 \mathrm{~kg}$ sijena. $U$ subasocijacijskom (suvljem) tipu Xerobrometum prinos je znatno niži i to zelene mase 2972 , a kod siiena $1.488 \mathrm{~kg}$. Ovako nicki prinosi posijedica su toga što se u toku proljeća na ovoj povrł̌ni vršila ispaša.

U asocijaciji Nardetum strictae prosječan prinos po ha iznosio je zelene krme $5.290 \mathrm{~kg}$, a sijena $1.669 \mathrm{~kg}$.

Asocijacija Calluneto-genistetum dala je stvarno najmanje prinose $i$ to zelene krme $3.252 \mathrm{~kg}$, a sijena $1.440 \mathrm{~kg}$.

Dolinske livade asocijacijskng tipa Cynosuretum cristati i Arrhenatheretum elatiorjs nastale prirodnim snošenjem hranjivih materija sa višil položaja na niže daju znatno veće prinose kako zelene krme tako i sijena. Asocijacija Cynostretum cristati (i to jedna varijanta na vrlo vlažnom staništu) dala je $21.000 \mathrm{~kg}$ zelene $\mathrm{krme}$, ili $7.000 \mathrm{~kg}$ sijena po ha, dok je jedna sastojina asocijacije Arrhenatheretum elatioris (koja je bila torenaj dala $22.000 \mathrm{~kg}$ zelene krme ili $6.832 \mathrm{~kg}$ sijena po ha.

Iz ovih padataka jasno se vídi da se pojedini tipovi livada i pašnjaka bitno razlikuju u ekonomskom pogledu, te da je stoga važno izvršiti khasifjk əciju livada i pašnjaka na florističkoj osnovi te sa gospodarskog stanovista. 
$\mathbf{P} \mathbf{E}$

hemijske analize sijena

\begin{tabular}{|c|c|c|c|c|c|}
\hline & $\begin{array}{c}\text { Tip livade } \\
\text { (asoeijacije) }\end{array}$ & $\begin{array}{c}\text { Vlaga } \\
\%\end{array}$ & $\begin{array}{c}\text { Pepeo } \\
\%\end{array}$ & $\begin{array}{c}\mathrm{P}_{3} \mathrm{O} \\
\%\end{array}$ & $\begin{array}{l}\text { Ukupni } \\
\text { azot }\end{array}$ \\
\hline 1. & $\begin{array}{l}\text { Agrostidetum } \\
\text { Bijele Vodice }\end{array}$ & 8,40 & 5,28 & 0,30 & 1,54 \\
\hline 2. & $\begin{array}{l}\text { Agrostidetum } \\
\text { Bijele Vodice }\end{array}$ & 7,81 & 5,35 & 0,34 & 1,25 \\
\hline 3. & $\begin{array}{l}\text { Agrostidetum } \\
\text { Bijele Vodice }\end{array}$ & 8,49 & 5,29 & 0,25 & 1,24 \\
\hline 4. & $\begin{array}{l}\text { Agrostidetum } \\
\text { Podtisovac }\end{array}$ & 8,54 & 5,56 & 0,16 & 1,40 \\
\hline 5. & $\begin{array}{l}\text { Agrostidetum } \\
\text { Jelovac blizu Mrzlih Vodica }\end{array}$ & 8,13 & 5,32 & 0,31 & 1,53 \\
\hline 6. & $\begin{array}{l}\text { Xerobrometum } \\
\text { Na putu ka Gornjem Jelenju }\end{array}$ & 9,56 & 6,04 & 0,15 & 1,66 \\
\hline & $\begin{array}{l}\text { Mesobrometum } \\
\text { Podtisovac }\end{array}$ & 8,75 & 5,45 & 0,16 & 1,63 \\
\hline 8. & $\begin{array}{l}\text { Mesobrometum } \\
\text { Podtisovac }\end{array}$ & 8,22 & 4,49 & 0,21 & 1,32 \\
\hline 9. & $\begin{array}{l}\text { Nardetum } \\
\text { Glocevac }\end{array}$ & 9,41 & 5,36 & 0,44 & 1,51 \\
\hline & $\begin{array}{l}\text { Nardetum } \\
\text { Bijele Vodice }\end{array}$ & 8,29 & 5,38 & 0,25 & 1,81 \\
\hline & $\begin{array}{l}\text { Cynosuretum } \\
\text { Mrzle Vodice }\end{array}$ & 8,83 & 6,80 & 0,23 & 1,37 \\
\hline 12. & $\begin{array}{l}\text { Arrhenatheretum } \\
\text { Mrzle Vodice prema Jelenju }\end{array}$ & 9,06 & 5,65 & 0,23 & 1,29 \\
\hline
\end{tabular}

UPOREDENJE BOTANICKE KATEGORIZACIJE SIJENA

SA SKROBNOM VRIJEDNOSTI

\begin{tabular}{|c|c|c|c|c|c|c|c|c|}
\hline Tip livade & 总 & 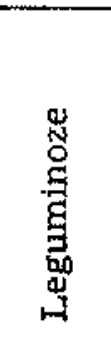 & 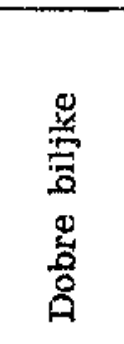 & $\begin{array}{l}5 \\
\text { 歌 } \\
\text { 员 }\end{array}$ & 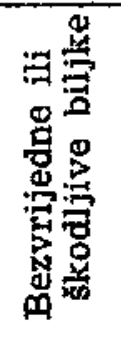 & 蚭 & 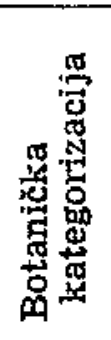 & 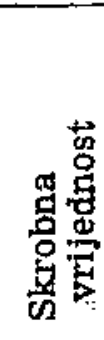 \\
\hline 1. Agrostidetum & 73,88 & 6,48 & 7,20 & 0,10 & 5,54 & 6,80 & I & 33,35 \\
\hline 2. Xerobrometum & 43,90 & 11,02 & 19,04 & 1,68 & 15,02 & 9,34 & II & 31,86 \\
\hline 3. Mesobrometum & 54,20 & 15,74 & 2,58 & - & 24,34 & 3,14 & II & 31,54 \\
\hline 4. Nardetum & 16,48 & 1,00 & 14,24 & 2,88 & 60,82 & 4,58 & III & 29,38 \\
\hline 5. Cynosuretum & 62,22 & 6,00 & 3,88 & 1,76 & 21,10 & 5,04 & II & 28,90 \\
\hline 6. Arrhenatheretum & 67,09 & 5,61 & 5,92 & 0,16 & 10,96 & 10,26 & $I$ & 34,05 \\
\hline
\end{tabular}


G L E D

pojedinth asocijacija

\begin{tabular}{|c|c|c|c|c|c|c|}
\hline $\begin{array}{c}\text { Azot } \\
\text { bjelan- } \\
\text { cevina } \\
\%\end{array}$ & $\begin{array}{c}\text { Surove } \\
\text { bjelan- } \\
\text { čevine } \\
\%_{0}\end{array}$ & $\begin{array}{l}\text { Ciste } \\
\text { bjelan- } \\
\text { Cevine } \\
\%\end{array}$ & $\underset{\substack{\text { Surove } \\
\text { masti }}}{ }$ & $\begin{array}{c}\text { Surova } \\
\text { vlakna } \\
\%\end{array}$ & $\begin{array}{c}\text { Azotne } \\
\text { ekstraktivne } \\
\text { sibstance } \\
\%\end{array}$ & $\begin{array}{c}\text { Bezazotne } \\
\text { elrstraktivme } \\
\text { substance } \\
\%\end{array}$ \\
\hline 1,26 & 9,62 & 7,90 & 2,81 & 32,25 & 1,72 & 41,64 \\
\hline 1,18 & 7,82 & 7,39 & 2,99 & 32,88 & 0,43 & 43,15 \\
\hline 1,11 & 7,73 & 6,96 & 3,45 & 34,41 & 0,77 & 40,63 \\
\hline 1,25 & 8,76 & 7,75 & 3,63 & 32,76 & 1,01 & 40,75 \\
\hline 1,27 & 9,55 & 7,94 & 2,89 & 30,36 & 1,61 & 43,75 \\
\hline 1,33 & 10,39 & 8,34 & 3,47 & 26,25 & 2,05 & 44,29 \\
\hline 1,25 & 10,21 & 7,80 & 2,79 & 33,27 & 2,41 & 39,53 \\
\hline 1,04 & 8,25 & 6,52 & 1,95 & 33,07 & 1,73 & 44,02 \\
\hline 1,25 & 9,43 & 7,84 & 3,04 & 31,16 & 1,59 & 41,60 \\
\hline 1,48 & 11,34 & 9,23 & 2,69 & 32,63 & 2,11 & 39,67 \\
\hline 1,03 & 8,58 & 6,45 & 3,14 & 33,76 & 2,13 & 38,89 \\
\hline 0,96 & 8,09 & 6,00 & 2,73 & 35,78 & 2,09 & 38,69 \\
\hline
\end{tabular}

\section{Upoređenje botaničkre kategorizacije sijena i skrobne vrijednosti}

$\mathrm{Za}$ ocjenu vrijednosti sijena botanička i hemijska analiza pretstavljaju važne elemente, ali ipak same za sebe nisu dovoljne za donosenje zaključaka o općoj hranljivoj vrijednosti sijena. Za ocjenu opće hranljive vrijednosti sijena neophodno je potrebno utvrditi njegovu svarljivost, odnosno koeficijente svarljivosti za pojedine hranljive materije sadržane u njemu (bjelančevine, masti, bezazotne ekstraktivne materije i celuloze).

Izračunavanje skrobne vrijednosti pretstavlja veliku teskoću kada se ne raspolaže podacima o svarljivim hranljivim materijama u svakom tipu (asocijaciji). Teškoća je $u$ tome sto se ne mogu primijeniti odgovarajući koeficijenti svarljivosti iz stručne literature, jer takvi koeficijenti nisu odredeni na pojedinim tipovima sijena, nego uopcé vrijede za one kvalitete sijena koji variraju u širokim granicama kao, npr. za sijena bogata proteinom, srednjeg kvaliteta, siromašna u proteinu i sl. Jasno je onda da na ovakav način izracunati skrobni ekvivalenti imaju samo ograničenu vrijednost. U izracunavanju skrobnih ekvivalenata $u$ 
Pregled prinosa zelene mase $i$ sijena $\mathbf{u}$ pojedinim asocijacijama

\begin{tabular}{|c|c|c|c|c|c|c|}
\hline Asocijacija & Mjesto & 蒂惫 & 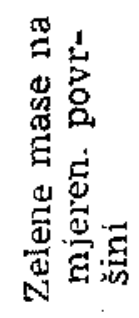 & 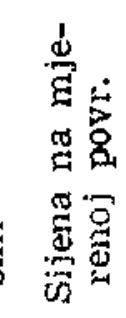 & 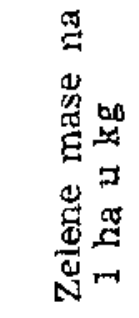 & 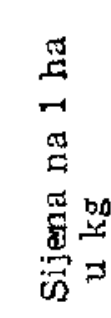 \\
\hline 1. Agrostidetum & Bijele Vodice & $1 \mathrm{~m}^{*}$ & 0,813 & 一 & 8,130 & 一 \\
\hline 2. Agrostidetum & $\begin{array}{c}\text { Livada nad } \\
\text { Jelenjem }\end{array}$ & $25 \mathrm{~m}^{2}$ & 34,6 & 8,19 & 13,840 & 3,276 \\
\hline 3. Agrostidetum & Bijele Vodice & $25 \mathrm{~m}^{2}$ & 32,3 & 10,20 & 12,920 & 4,080 \\
\hline 4. Agrostidetum & Bijele Vodice & $25 \mathrm{~m}^{2}$ & 32,4 & 12,96 & 12,960 & 5,184 \\
\hline 5. Agrostidetum & Bijele vodice & $1 \mathrm{~m}^{\prime \prime}$ & 1,54 & 0,50 & 15,400 & 5,000 \\
\hline 6. Agrostidetum & Bijele Vodice & $25 \mathrm{~m}^{2}$ & 51,2 & 19,20 & 20,480 & 7,680 \\
\hline 7. Xerobrometum & $\begin{array}{l}\text { Na putu ka } \\
\text { Gornjem Jelenju }\end{array}$ & $25 \mathrm{~m}^{4}$ & 7,43 & 3,72 & 2,972 & 1,488 \\
\hline 8. Mesobrometum & Clnoluški Zelin & $25 \mathrm{~m}^{2}$ & 22,5 & 6,75 & 9,000 & 2.700 \\
\hline 9. Mesobrometum & Crnoluški Zelin & $25 \mathrm{~m}^{*}$ & 23,63 & 8,2 & 9.452 & 3.280 \\
\hline 10. Mesobrometum & $\begin{array}{l}\text { Padine iznad } \\
\text { rezervoara }\end{array}$ & $25 \mathrm{~m}^{2}$ & 20,9 & 7,3 & 8.360 & 2.920 \\
\hline 11. Mesobrometum & Podtisovac & $25 \mathrm{~m}^{2}$ & 27,0 & 13,25 & 10.800 & 5.300 \\
\hline 12. Nardetum & Glocevac & $1 \mathrm{~m}^{*}$ & 0,795 & 0,20 & 7.950 & 2.000 \\
\hline 13. Nardetum & Bijele Vodice & $25 \mathrm{~m}^{3}$ & 8,0 & 2,8 & 3.200 & 1.120 \\
\hline 14. Nardetum & $\begin{array}{c}\text { Nad Bijelim } \\
\text { V:odicama }\end{array}$ & $25 \mathrm{~m}^{2}$ & 11,80 & 4,72 & 4.720 & 1.888 \\
\hline $\begin{array}{l}\text { 15. Calluneto- } \\
\text { genistetum }\end{array}$ & Bijele Vodice & $25 \mathrm{~m}^{2}$ & 8,13 & 3,6 & 3.252 & 1.440 \\
\hline 16. Cynosuretum & Mrzla Vodica & $10 \mathrm{~m}^{2}$ & 21,0 & 7,0 & 21.000 & 7.000 \\
\hline 17. Amhenatheretum & $\begin{array}{l}\text { Prema Gornjem } \\
\text { Jelenju }\end{array}$ & $25 \mathrm{~m}^{2}$ & 55,0 & 17,18 & 22.000 & 6.872 \\
\hline
\end{tabular}

konkretnom slučaju poslužio sam se Kellner-Fingerlingovim koeficijentima probavljivosti.

Za Agrostidetum tip uzeti su koeficijenti svarljivosti koji su navedeni kod Kellner-Fingerlinga za sijena Agrostidetum vulgaris. Za ostale tipove, s obzirom na njihovu botanixku klasifikaciju, uzeti su koeficijenti svarljivosti koji prema Kellner-Fingerlingu odgovaraju srednjem, dobrom ili vrlo dobrom sijenu. Kad se razmatraju tako dobivene vrijednosti za pojedine tipove sijena može se konstatovati da postoji izvjesna podudarnost između botaničkih klasifikacija i skrobnih vrijednosti za svaki navedeni tip.

Prema Kellner-Fingerlingovoj klasifikaciji Xerobrometum $i$ Mesobrometum tip sijena spadao bi u dobro sijeno. Nardetum tip spadao bi u manje dobro sijeno. Arrhenatheretum tip spadao bi $u$ dobro do vrlo dobrog sjjena. U konkretnom slučaju Cynosuretum tip spadao bi u grupu manje dobrog do dobrog sijena, što ne bi bilo u skladu sa shvatanjem o tipu Cynosuretum, koji inace spada u dobro sijeno. Među- 
Graf. I. Grafičlki prikaz pokrovnosti biljaka izražen u procentima u pojedinim asocijacijama (subasocijaci jama)

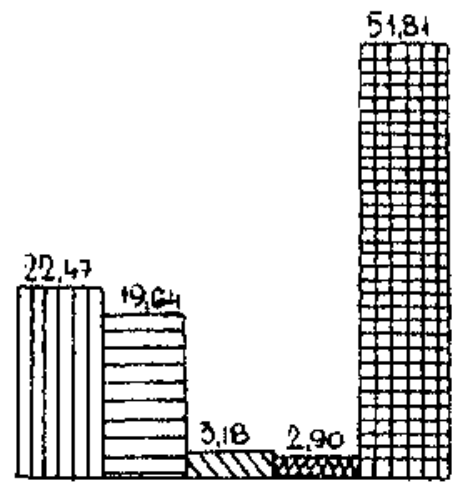

ME SORDOME TUM

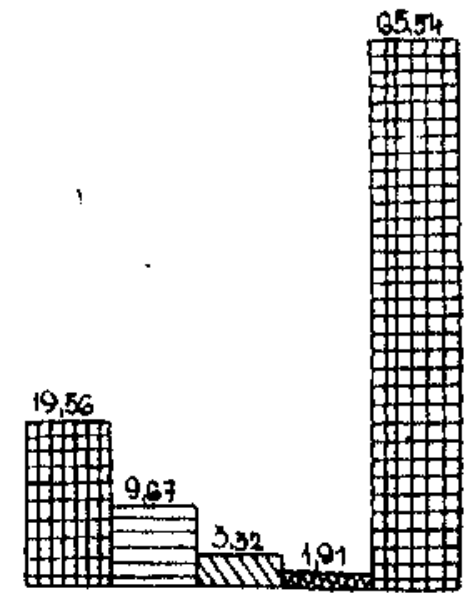

XERORRTIETUN.

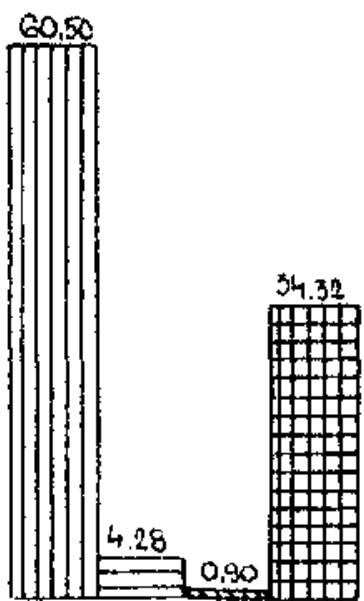

WARIE ? U上
A

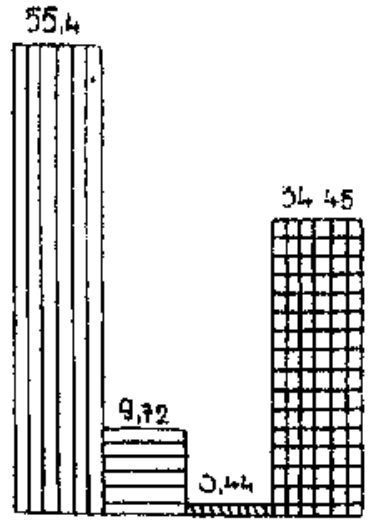

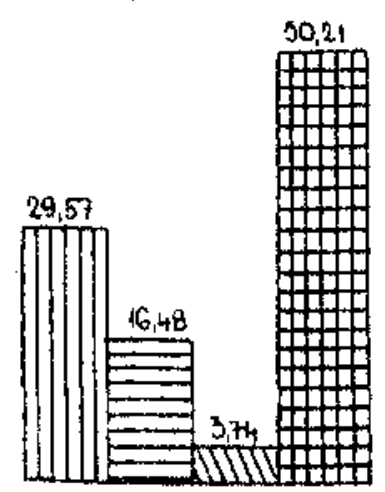

ARRHEHATHEDETUM

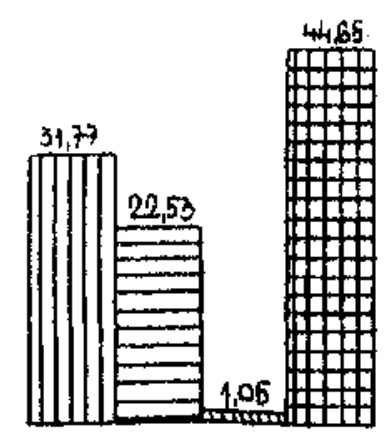

LYNOSUREIUM

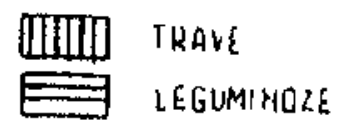

STASEVI

MAHUVINE

E地 USTALE ZELJASIE BLLJKE 
tim, u Cynosuretum tipu postoji nekoliko varijanata, a kako se iz botanicke analize dade vidjeti ovaj uzorak sijena uzet je sa barovitog staništa, zbog čega nastaje otstupanje.

Iz grafikona I proizlazi veliko podudaranje u procentualnom sastavu asocijacije Bromus erectus - Plantago media, ali takode se vidi i to. da se pojedine subasocijacije (Mesobrometum i Xerobrometum) u izvjesnoj mjeri razlikuju.

U subasocijaciji Mesobrometum javlja se veći broj Ieguminoza, dok. su u subasocijaciji Xerobrometum više zastupljene zeljaste vił̌egodišnje biljke. U objema subasocijama se, nadalje, vidi da prevladuju zeljaste biljke nad travama. Trave $i$ šaševi nalaze se $u$ obje subasocijacije u jednakom procentu. Sličnost u pokrovnosti pojedinih skupova bigaris i Nardetum strictae. U jednoj i drugoj asocijaciji pretežu trave preko $55-60 \%$, a ostale zeljaste biljke nalaze se do $34 \%$. Razlike poljaka vidi se izmedu dvije daljnje livadne asocijacije Agrostidetum vulstoje i u leguminozama iako nisu naročito velike. Uprkos tome sto su. te dvije asocijacije po množini trava i zeljastih biljaka neobično slične, one se ipak bitno razlikuju ne samo $u$ prinosu nego i u florističom. sastavu, a po tome i u ekonomskoj vrijednosti.

$U$ asocijaciji Arrhenatheretum i Cynosuretum pretežu ostale zeljaste biljke $(44,65-50,21 \%)$, dok se trave i saševi razlikuju u neznatnom procentu. U asocijaciji Cynosuretum cristati Typicum znatno preovladaju leguminoze $u$ odnosu na tip Arrhenatheretum.

Upoređenje grafik, II, III i IV, gdje su sve vrste svrstane po ekonomskoj vrijednosti, pokazuje goleme razlike izmedu pojedinih asocijacija, dok se unutar asocijacija vidi uglavnom veliko podudaranje. U asocijaciji Agrostidetum vulgaris naročito dvije donje površne pokazuju vanredno podudaranje. Struktura pokazuje jednoliki sastav, tako da dobre krmne trave pretežu sa preko $74-75 \%$, dok su ostale zeljaste. biljke zastupljene $u$ jednakom procentu, a neznatne razlike postoje $u$ leguminozama. Suma ekonomskih dobrih krmnih vrsta (trava, leguminoza i ostalih biljaka) podudara se $u$ pokrovnosti, $88-.90 \%$, a time $i$ u ekonomskoj vrijednosti. Gornja površina pretstavlja početni razvojni stadij livade, te zbog toga njena struktura ne pokazuje toliku podudarnost sastava sa dvjema prethodnim.

U grafik. III i IV vidno se po ekonomskoj vrijednosti istice asocijacija Arrhenatheretum $u$ kojoj trave, leguminoze i ostale zeljaste biljke iznose po pokrovnosti $79 \%$.

Asocijacija Cynosuretum ima nešto manji \% trava, a leguminoza $i$ : ostalih zeljastih biljaka $72 \%$. To proizlazi odatle sto je uzorak uzet, kako je već spomenuto, iz najvlažnije sastojine u kojoj se nalaze i neke. biljke mozvarnih livada.

Dalje grafikoni koji pretstavljaju asocijaciju Bromus erectus - Plantago media pokazuju da u subasocijacijama Xerobrometum i Mesobrometum pokrovnost trava i zeljastih biljaka iznosi gotovo jednak procenat $73-74 \%$. Razlike u leguminozama, a naročito $u$ ostalim zeljastim: biljkama, nastale su usljed ispaše na površini Xerobrometuma.

Prema tome, sve dosada navedene livade imaju veliki procenat. ekonomski dobrih biljaka. 
Grat. II. Grafički prikaz ekonomskih grupa biljaka izrax̌enih u procentima:u botaničkoj i težinskoj analizi sijena (asocijacija agrostidetum vulgaris)

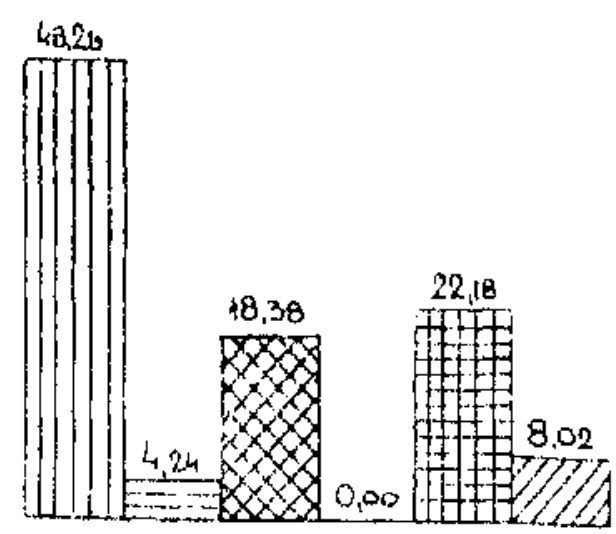

AGROSTIUETUM

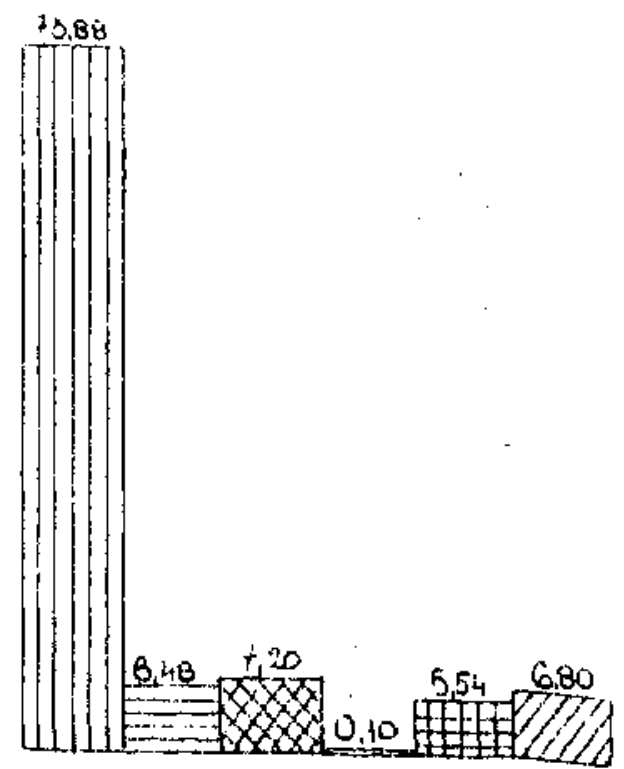

AGRQSTIDETUM

UIII] TRAVE

$\Rightarrow$ LEOUNHO2.

DUBRE BIUHE

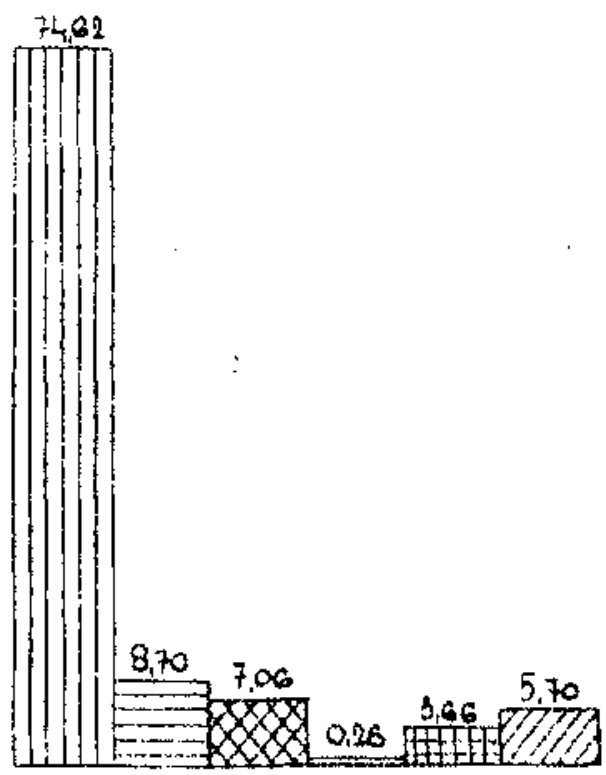

AGROSTIDETUM

SASEVI

GEZVREDHE IL S̈KUOLIVE BIJKE

TRIME 
Graf. II. Graficki prikax elconomskih grupa biljaka izraženih u procentima u boìnlěkoj i težinskoj analizi sijena pojedinih asocijacija (subasocijacija)

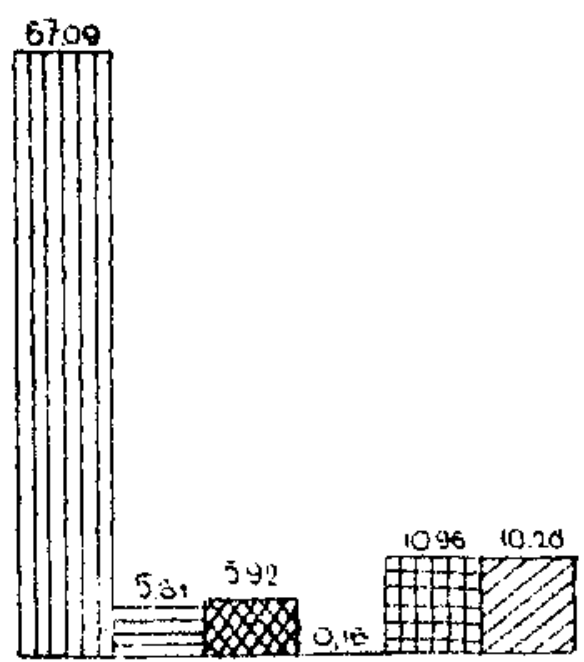

ARRHENATHERETUM

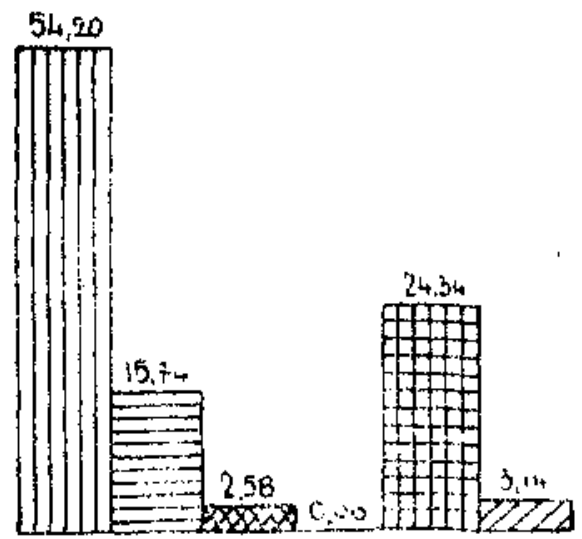

Me Sogromerum

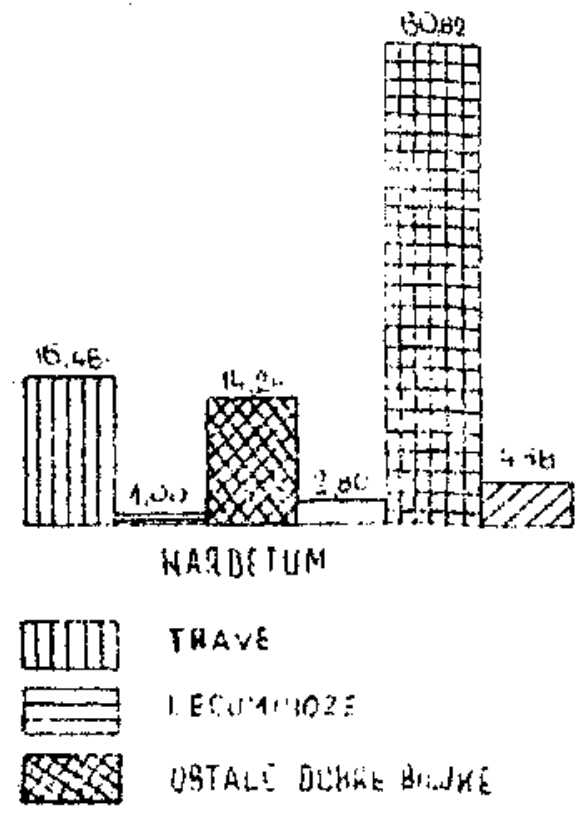

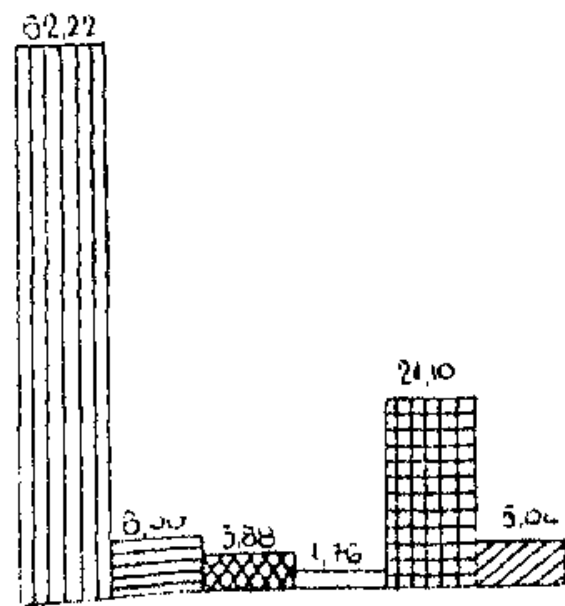

CYMOSURETU:-

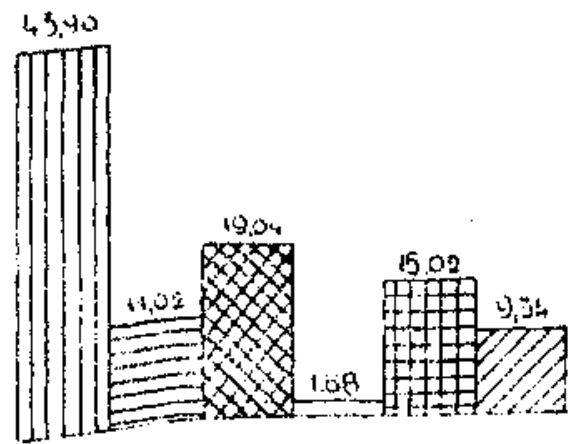

XF ROHR,JMF $T_{1}, M^{2}$

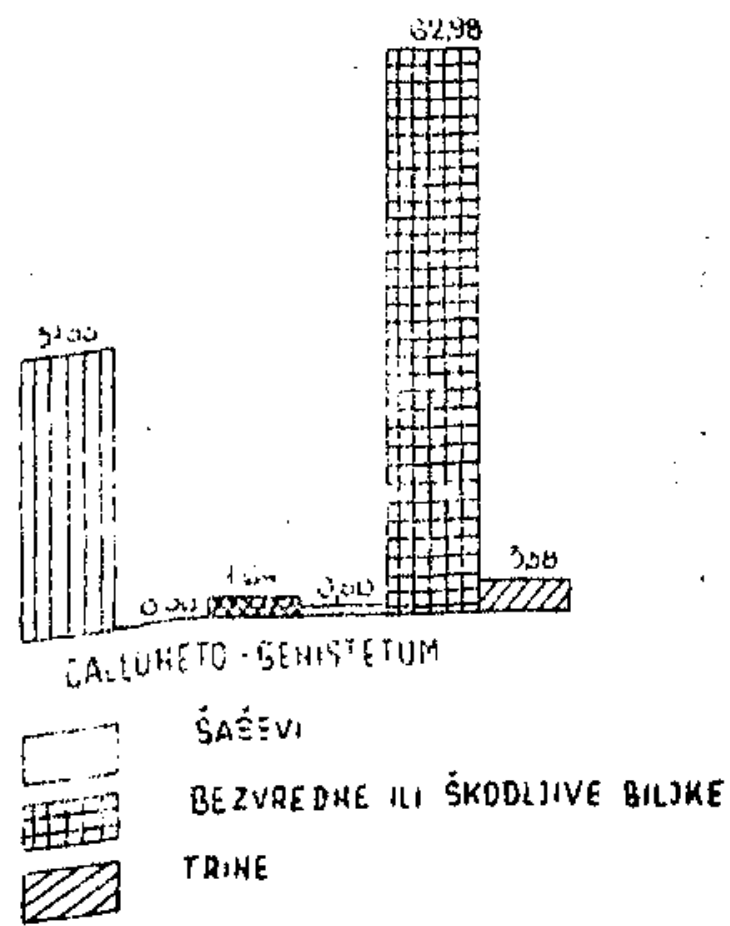


Graf. IV. Shema ekonomski dobrih ksmnil vrsta trava, leguminoza i ostalih dobrih versta

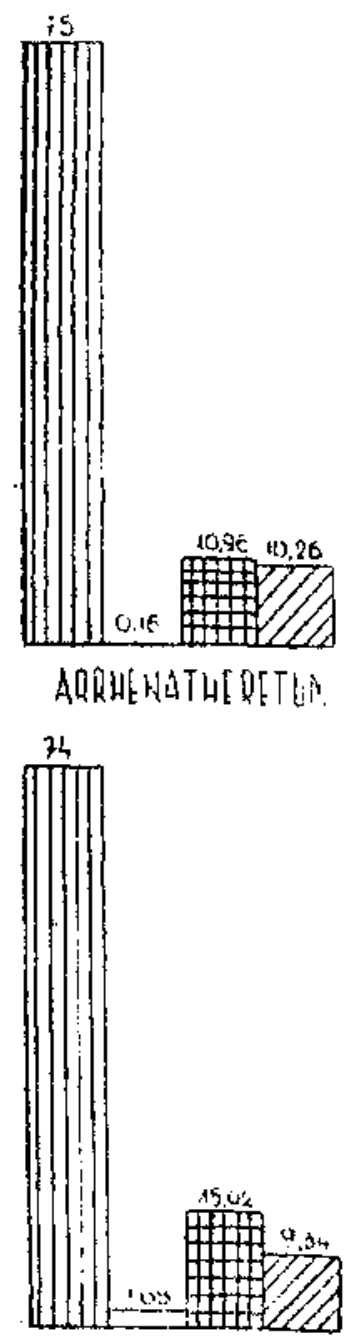

XE RuBdidtlatu
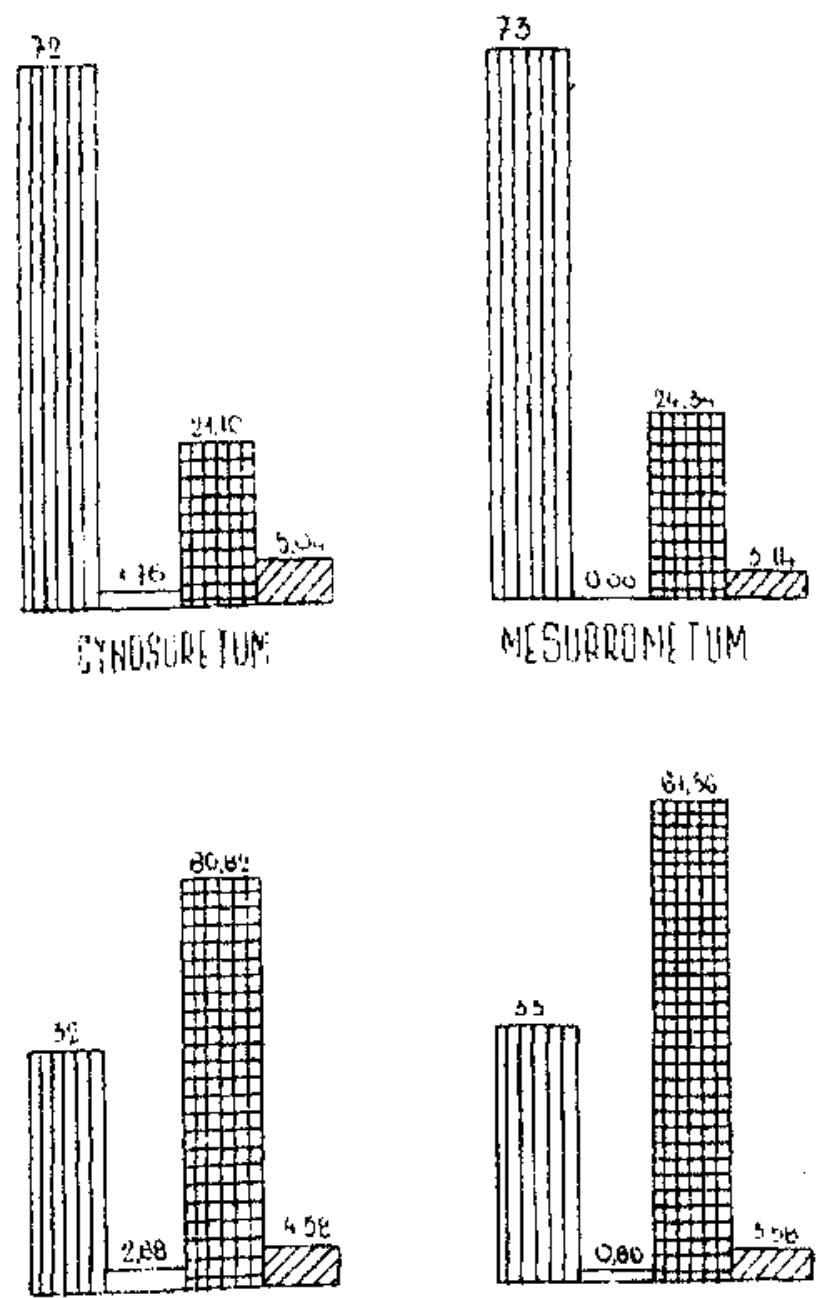

HARLETUM

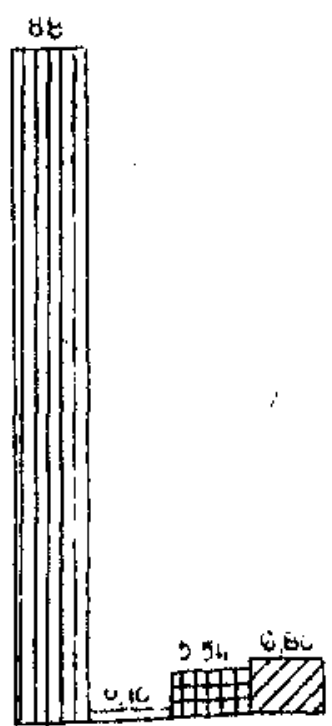

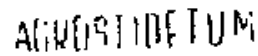

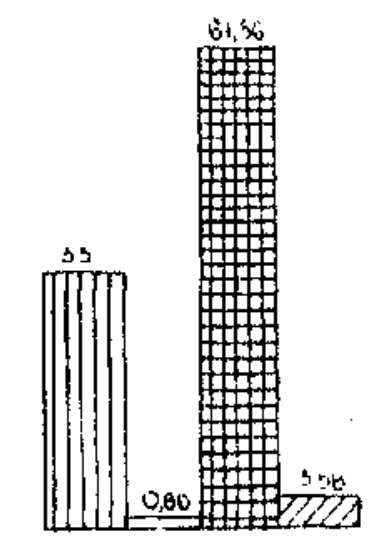

EALIIIHETO - GEHISTETUM

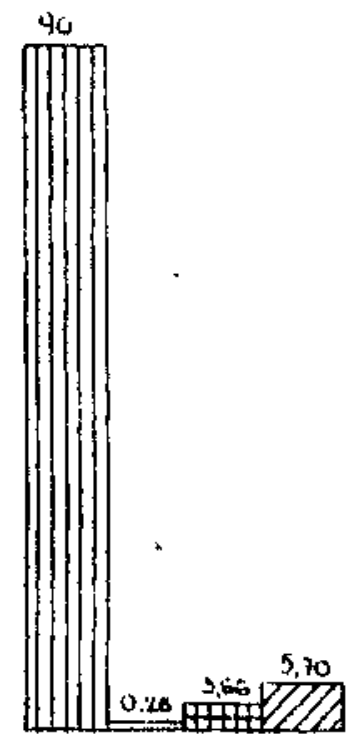

AGNUSTIDETUM

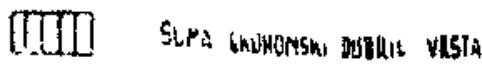


Bitno se razlikuju daljnje dvije asocijacije (Nardetum strictae i Calluneto - Genistetum) kaje, lako se međusobno po strukturi mnogo raalikuiu, 'pak imaju veoma mali (32-33\%) procenat ekonomski dobrih biljaka, - dakle samo jednu polovinu, do jedne trećine ekonomski vrijednih vrsta, prema ostalim livadnim tipovima.

Graf. V. Prosječni prinosi zelene krme i sijena s ekonomski dobrim vrstama u lkiogramima na 1 ha.

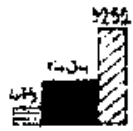

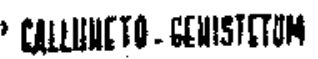

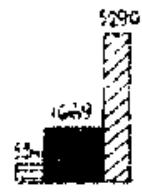

MABTTH

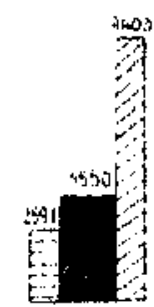

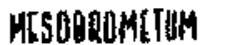

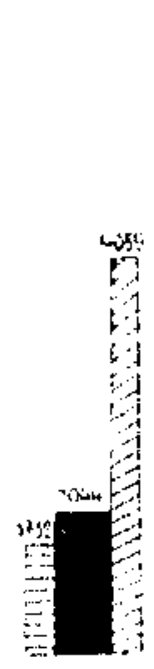

ACEOSTIDTTUM

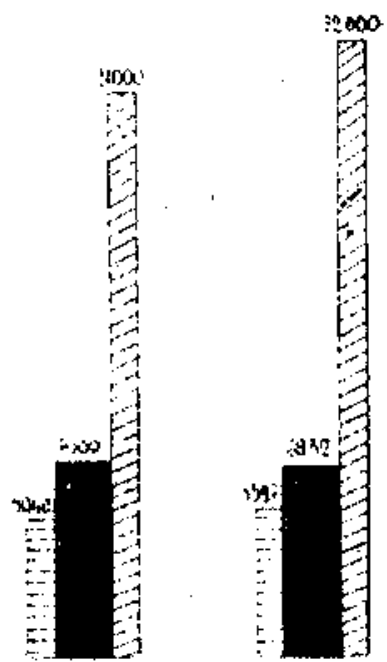

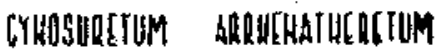

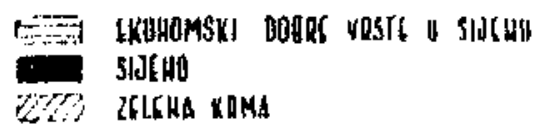

U grafikonu V vidno se ističe faktor isušivanja zelene krme u livadnim tipovima Arrhenatheretum, Cynosuretum, Agrostidetum, Mesobrometum, koji pretstavljaju sočnu zelenu krmu, dok faktor isušivanja zelene krme asocijacijslrog tipa Nardetum i Calluneto - Genistetum je zaatno manji.

Uporedenja sume ekonomski dobrih krmnih vista zastupljenih u sijenu pojedinih tipova doprinosi procjeni vrijednosti pojedinih asocijacija sa ekonomskog gledišta.

\section{TEMELJNE SMJERNICE ZA MELIORACIJSKE RADOVE}

Ekonornska vrijednost pojedinih asocijacijskih tipova: Agrostidetum, Bromus erectus - Plantago media, Nardetum stricta i ostalih je razlicita, a zavisi kako od klime, tla, načina iskorisćavanja travne tratine, tako i od primjene niza odgovarajucilh tehnickih i agrotehnickih mjera.

Ovdje cemo se ukratko osvrnuti na tehnicke i agrotehničke mjere, koje mogu da se primijene u pojedinim stadjjima određenih tipova 
livada i pašnjaka u cilju promjene njihovog biljnog pokrivača ili prevođenja jednog tipa u drugi radi njihovog što boljeg iskorištavanja sa gospodarskog stanovišta.

Kao što je već ranije pomenuto $u$ ekološkom podrucju asocijacijskog tipa Agrostidetum poslije njivskih kultura prepušta se oranica samozatravljivanju, ili se ponekad zasijava trinama. U ovom poctetnom stadiju treba imati na umu da u stvaranju travne tratine na napuštenoj njivi imaju najvećeg udjela zeljaste biljke iz raznih porodica, što se objašnjava povoljnom strukturom tla i povoljnim odnosom, izmedu vlage, toplote, mikroflore $i$ drugog $u$ tlu.

U cilju otklanjanja nejednoličnosti kvantitativnog a naročito kvalitativnog sastava travne tratine u stadiju zeljastih biljaka, treba spriječiti zasijavanje livada trinama sijena, jer trine dovode kao i samozatravljivanje do zakorovljivanja, nego treba te površine zasijati travno-djetelinskim smjesama.

Drugi stadij razvitka travne tratine ovog tipa, nastaje kao posljedica smanjenja aerobnih uslova usljed nagomilavanja organske materije, a time i vlage. $U$ ovom stadijumu javljaju se trave rastresitog bokora i leguminoze žbunastog oblika. Pored trava i leguminoza u sastav asocijacije ovog stadija dolaze i biljke ostalih porodica.

Sa poljoprivredne tačke gledišta najbolje je vrijeme za iskorišćavanje travne tratine izmedu I i II stadija pošto može da se koristi kako za proizvodnju sijena tako i za ispašu. Ovaj drugi stadij, koji je karakterisan asocijacijskim tipovima Agrostidetum vulgaris, Arrhenatheretum elatioris, Bromus erectus - Plantago media, Cynosuretum cristati i 'Trisetetum flavescentis pretstavlja ustvari zrelost travne tratine i veoma brzo reaguje na agrotehničke mjere (đubrenje i dr.).

Treći stadij razvitka travne tratine javlja se kao posljedica anaerobnih uslova, te u tratini dominiraju trave zbijenog busena, čiji se čyor bokorenja nalazi nad zemljom, a leguminoze se uopće ne razvijaju, ili se razvijaju u vrlo maloj mjeri. U ovom stadiju na travnoj tratini rastu biljke koje nisu sposobne da se hrane autotrofno već mikotrofno. Ovaj stadij karakterisan je asocijacijskim tipom Nardetum strictae.

Većina agrotehničkih mjera (osim torenja) koje se primjenjuju u ovom stadiju travne tratine pokazuje slabo ili kratkotrajno djelovanje, jer njihov efekat često nije u skkladu s trošlkovima oko njihovog izvodenja. Prema Vilij a ms u apravdano popravljanje travnih tratina u ovom stadiju (asocijacija Nardetum strictae) je preoravanje uz prethodni plodored, te poslije toga podizanje novih umjetnih livada ili pašnjaka.

Kao značajnu mjeru u području asocijacijskog tipa Agrostidetum vulgaris na napuštenim oranicama potrebno je izvrక̌iti pravilan izbor trava za sjetvu, odnosno izabrati samo one trave koje pri datim uslovima daju najbolji prinos I stočnu hranu najboljeg kvaliteta. Za pravilan izbor trava neophodno je potrebno poznavanje prirodnih uslova, tj. klime i tla, $s$ jedne strane, $i$ bioloških osobina samoniklih, ali dobrih biljaka, $s$ druge strane. Izbor biljaka za travno-djetelinske smjese treba da se oslanja na fitocenološka istraživanja dotienog područja. Na osnovu fitocenoloških snimanja utvrđuje se koje su korisne trave i leguminoze i druge korisne biljke dobre krmne vrijednosti zastupljene na travnoj tratini sa većom pokrovnosću, pa se obavezno uzimaju pri sastavljanju 
travno-djetelinskih smjesa kod podizanja umjetnih livada i pašnjaka. Primjeri smjesa za umjetne livade i pašnjake, koje nalazimo u literaturi, imaju ograničenu vrijednost, jer su date tabele sastavljene za odrefene klimatske $i$ zemljišne uslove, te ne mogu poslužiti za raznorazna područja.

Stoga, kao što navodi $V$. Đordević $u$ knjizi Li vadalst vo 1 pašnjarstvo 1951 godine), one mogu da posluže samo kao orijentacioni obrazac za sastavljanje travno-djetelinskih smjesa za umjetne livade i pašnjake, a za svaki kraj treba posebno sastaviti travno-djetelinske smjese koje odgovaraju lokalnim prilikama.

U Gorskom Kotaru, u području asocijacijskog tipa Agrostidetum vulgaris, od trava u smjesi treba upotrebiti sljedece vrste: Agrostis vulgaris, Festuca rubra, Festuca pratensis, Cynosurus cristatus, Phleum pratense, Poa pratensis, Trisetum flavescens i Lolium perenne, a od leguminoza Trifolium pratense, Trifolium repens, Lotus corniculatus i Medicago lupulina.

$\mathrm{U}$ pogledu prostih travno-djetelinskih smjesa u području asocijacijskog tipa Agrostidetum vulgaris na njivama u cilju popravke strukture tla, s jedne strane, $i$ dobijanja krme, sa druge strane, treba uzimati smjesu Trifolium pratense sa Phleum pratense. Ovu travu preporucujem zbog toga sto se $u$ ovom podruçju na mnogim mjestima gaji tzv. "travulja (Phleum pratense) za proizvodnju sjemena, a koja daje' veoma dobre i ujednačene prinose.

Pri podizanju umjetnih livada u području asocijacijskog tipa Bromus erectus - Plantago media od trava u toj smjesi treba upotrijebiti sljedeće vrste: Bromus erectus, Dactylis glomerata, Festuca pratensis, Festuca rubra, Trisetetum flavescens $i$ Arrhenatheretum elatius, a od. leguminoza Medicago falcata, Hippocrepis comosa, Lotus corniculatus i obzir Bromus erectus $i$ Medicago falcata.

Anthyllis vulneraria. Za proste travno-djetelinske smjese došao bi u

Na promjenu asocijacijskog tipa ima veoma jak uticaj, pored ostalih, nepovoljan vodni režim $u$ tlu, $i$ to kako pretjerana vlažnost tako i nedostatak vlage.

U subacocijacijskom tipu Xerobrometum, zbog nepovoljnog vodnog režima javljaju se mnoge kserofilne $i$ termofilne vrste, koje su čsto po krmnoj vrijednosti loše. Medutim u asocijacijskom tipu Cynosureturm često se javljaju varijante sa pretjeranom vlažnošču, tako da se javljaju u travnoj tratini mnogobrojne hidrofilne vrste, koje su ne samo loše po krmnoj vrijednosti nego su čak i otrovne po život stoke kao što su: Colchicum autumnale, Ranunculus acer, equisetun pahustre i druge.

Da bi se pojačao vodni režim u području subasocijacijskog tipa Xerobrometum, potrebno je, uz ostale mjere, podizanje sumskih pojaseva koji bi na travnoj tratini uslovili pojavu mezofitnih vrsta sa boljom krmnom vrijednošću. Istovremeno u subasocijacijskom tipu Xerobrometum treba primijeniti povrß̌insko aubrenje bilo putem torenja ili mineralnog đubrenja.

Uporedo s ovim mjerama u subasocijacijskim tipovima (Xerobrometum i Mesobrometum) mora se posvetiti pažnja načinu ispaše. Ispaša. se mora vršiti po turnusima, $t j$. iskorišćavanje pojedinih površna - 
dionica mora se vršiti utvrâtenim redom, tako da se pasnjaci ne gaze bez potrebe $i$ da se svaki njihov dio što potpunije iskoristi. Ovakvo povremeno iskorišćavanje jednog dijela i ostavljanje na odmoru drugog dijela omogucilo bi obnavljanje i jačanje korisnih biljaka ma travnoj tratint u najkraćen roku. Ako se ne pridržavamo turnusa prilikon ispaše u asocijacijskom tipu Bromus erectus - Plantago media stoka se zadržava dugo na istom mjestu, tlo se zbija, te usljed toga u njemu nastupaju anaerobni procesi, što uslovljava razvoj travne tratine zbijenog busena, tj. biljaka mikotrofnog tipa ishrane. Ovakav razvitak travne tratine isključuje porast dobrih $\mathrm{krmnih}$ biljaka, te asocijacijski tip Bromus erectus - Plantago media prelazi u degradirani tip Nardetum strictae.

Brananjem, kao važnom agrotehničkom mjerom, vrši se aeracija tla u travnoj tratini. Ova bi mjera pokazala pozitivno djelovanje u asocijacijskom tipu Agrostidetum u kome su zastupljene jačom pokrovnošću rizomne trave, zatim trave rastresitog bokora, kao i leguminoze kod kojih je korijenov rast smješten dublje u zemlju. Brananjem se dalje s jedne strane prorahljuje plitak zemljišni sloj, a s druge strane rasturaju se krtičnjaci i mravinjaci. Mehanizacija košenja livade tipa Agrostidetum, Arhenatheretum i Cynosuretum, bilo zaprežnom ili motornom kosačicom, traži rasturanje krtičnjaka i mravinjaka. Krtice i mravi izbacuju po površini livade zemlju u obliku humaka, koji se poslije nekog vremena zbijaju i obrašcuju korovskim biljkama. Brananjem se lako vrši rasturanje svježih krtičnjaka, jer je zemljište nad krtičnjakom meko i sipko. Dovoljno je da se u proljeće i jesen prode livadnom branom i da se izvrši rasturanje i poravnanje zemljišta. Brananjem se ujedno skidaju i mahovine, lako je rad livadnih brana na uništavanju mahovine djelomičan i slab, pošto se ovom mjerom ne mogu ukloniti uzroci koji izazivaju pojavu rasta mahovine. Ove se mahovine javljaju najcesce na kiselim tlima, pa se njihovo otklanjanje postiže provadanjem brananja i đubrenja.

Đubrenje kao agrotehnička mjera ima posebnu važnost u svim asocijacijskim tipovima. Ono može biti izvedeno u raznim vidovima pomoću mineralnih i organskih dubriva. Dubrenjem travnih tratina postiže se popravljanje fizičkih, hemijskih i bioloških osobina tla, povećanje prinosa, izmjena botaničkog sastava travne tratine, suzbijanje nekorisnih i za zdravlje stoke škodljivih biljaka, te popravljanje sastava stočne hrane, naročito u odnosu na sadržaj u bjelančevinama.

Za kvaiitet sijena ima presudnu văžnost pravovremeno košenje. Đubrenje $i$ druge agrotehṇičke mjere ne mogu osigurati potpun uspjeh ako se zakasni sa košenjem. Zakašnjavanje sa košenjem ispoljava se u lošem kvalitetu sijena, osim toga košenjem livade kad su se osjemenile i rasturile mnogobrojne nekorisne štetne biljke potstiče se rast korova, a time utiče na smanjenje prinosa u sljedecoj godini.

$\mathrm{Za}$ potpun uspjeh u suzbijanju nekorisnih kao $\mathrm{i}$ otrovnih biljaka potrebno je primijeniti niz mjera koje se uglavnom sastoje u pravovremenoj kosidbi i pravilnoj ispaši, a za uništavanje biljaka koje se razmnožavaju lukovicama potrebno je vršiti uništavanje lukovica.

Naprijed tznesenim mjerama u mnogome bismo povecali proizvodnju stočne hrane po kvalitetu i kvantitetu i tako intenzivirali pasnjarstvo i livadarstvo, a preko njega i stočarstvo. 


\section{ZAKLJUCAK}

Cilj istraživanja bio je tijesno povezivanje botaničkih (biljnosocioloskih) i poljoprivrednih istraživanja sa zadatkom da se za jasno omeđene biljne zajednice (asocijacije, subasocijacije) dolinskih, brdskih livada i pašnjaka Gorskog Kotara utvrdi ekonomsko značenje i pronađu meliorativne mjere.

Metoda istraživanja. Sva poljoprivredna istaživanja vršena su isključivo na jasno omedenim zajednicama (tipovima), te su istraženi ovi elementi:

1) prinos zelene krme i sijena po 1 hektaru;

2) sastav i klasifikacija krme po pokrovnosti vrsta i njihovom ekonomskom značenju;

3) hemijski sastav sijena;

4) uticaj prirodnih $i$ antropogenih faktora na postanak i razvitak pojedinih tipova;

5) izgledi za melioraciju.

Rezultati.

1) Istraženi su sa poljoprivrednog gledišta ovi tipovi (asocijacije, subasocijacije):
a) asocijacija Bromus erectus - Plantago media subasocijacija Xerobrometum subasocijacija Mesobrometum
b) asocijacija Nardetum strictae
c) asocijacija Calluneto - Genistetum
d) asocijacija Agrostidetum vulgaris
e) asocijacija Cynosuretum cristati
f) asocijacija Arrhenatheretum elatioris

Građa i razvitak ovih livada zavisi od različitih faktora. Geolos̆ka podloga od krečnjaka ili silikata svojim hemijskim sistavom, uz vlagu, klimu i hranljive materije ima veliko znacenje na fizionomski izgled i formiranje biljnih asocijacija. Izgled, sastav i stanje brojnih asocijacija uslovljavaju ekoloske prilike i uticaj biotskih faktora. tipova.

2) Proucen je nadalje kvantitativni i kvalitativni sastav pojedinih

Utvrđeno je da je prinos zelene krme i sijena razlixit $u$ razlixitim tipovima i iznosi:

: subasocijacija Mesobrometum asocijacija Nardetum strictae

Callumeto-Genist.

" Agrostidetum vulg.

$9043 \mathrm{~kg}$. zel. krme ili sijena $3.550 \mathrm{~kg}$.

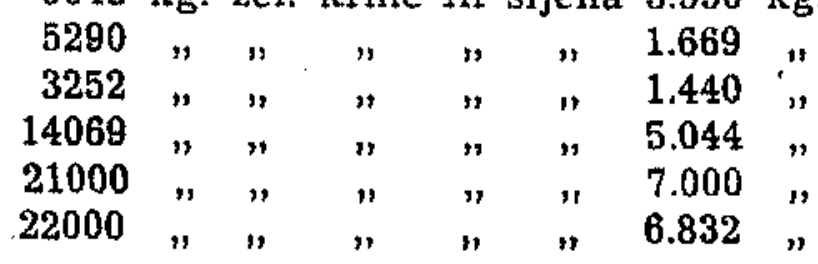
vršsina.

Variranje unutar tipova zavisi o ekonomskoj obradi dotičnih po- 
3) Između pojedinih tipova postoje velike razlike $u$ težinskom odnosu zastupljenosti leguminoza, trava i ostalih biljaka. Ovaj odnos prikazan je u grafikonima I, II, III, IV str. 41-44.

Po ekonomskom znaCenju biljne vrste svrstane $s u$ u kategorije A, B, C i D. Ovaj odnos prikazan je prema tabelama i to: za tip Bromus cerectus - Plantago media, Nardetum strictae, Agrostidetum vulgaris, Arrhenatheretum, Cynosuretum.

Pokrovna vrijednost vaganjem daje slikı o važnosti neke vrste ili grupe u samoj asocijaciji. Ona je od velikog praktičnog značaja kod sastavljanja travnih smjesa za dotično podnučje. Po florističkom sastavu u subasocijaciji Xerobrometum trave zauzimaju $19,56 \%$, a leguminoze $9,67 \%$, u subasocijaciji Mesolbrometum trave zauzimaju $22,46^{\circ} \%$, a leguminoze 19,44\%. U asocijaciji Agrostidetum vulgaris trave zauzimaju $55,4 \%$, a leguminoze $9,72 \%$.

U asocijaciji Cynosuretum cristati trave zauzimaju $31,77 \%$, a leguminoze zauzimaju 22,53\%. U asocijaciji Arrhenatheretum elatioris trave zauzimaju $29,57 \%$, a leguminoze $16,48 \%$.

4) Botanička i hemijska analiza sijena pretstavljaju važne elemente za ocjenu vrijednosti sijena, $\mathrm{Za}$ donošenje zaključaka o općoj hranljivoj vrijednosti sijena potrebno je poznavati njegovi svarljivost, odnosno koeficijente svarljivosti za pojedine hranljive materije sadržane ut njemu. (vidi tabelu na str. 36-37).

5) Livade su nastale potiskivanjẹ šume ili napuštanjem kultura pod uiticajem dubrenja. Asocijacija Agrostidetum vulgaris je kulturna livada, donekle Trisetetum i Arrhenatheretum, a ostale su prirodne.

6) Botanička i poljoprivredna istraživanja polrazuju da se svi tipovi brdskih livada i pašnjaka mogu pravilno melioracijom prevesti u odlične tipove dolinsko-brdskih livada: Arrhenatheretum, Agrostidetum i Trisetetum. Kao najbolji način obrade asocijacije Agrostidetum vulgaris preporučuje se poslije napuštanja kultura sijanje travno-djetelinskih smjesa koje su u ovom tipu zastupljene s najvećom pokrovnošću, a imaju visoku vrijednost $z$ a ishranu, te su prilagođene životnim prilikama staništa. Sastav vrsta naveden je u tabeli kod asocijacijskog tipaAgrostidetum vulgaris.

7) Konačni rezultat povezanih botaničkih i poljoprivrednih istraživanja pokazuje da su prirodne zajednice livada i pašnjaka, kako su pokazane od strane botaničara, najjednostavnija i najsigurnija polazna tačka za sva poljoprivredna istraživanja. 


\section{ZUSA M MENFASS UNG \\ LANDWIRTSCHAFTLICHE UNTERSUCHUNGEN DER BERG- UND TALWEIDEN UND WIESEN IM GORSKI KOTAR}

Der Zweek der Untersuchungen bestand in der innigen Verbindung. botanischer (pflanzensoziologischel') und landwirtschafticul in Untersuchungen mit der Aulgabe, den ökonomischen Wert chla! umgrenzter Pflanzengemeinschaften (Assoziationen, Subassoziationen) der Tal-und Ber'gwiesen und Wei-. den im Gorsixi Kotar festzustehen und enusprechende Meliorationsmassnabmell vorzunehmen.

Untersuchungsmethode. Alle landwirtschaftlichen Untersuchungen wur(ien an ausschliessiich klar unglenzten Gesellschaften (Typen) vorgenommen.

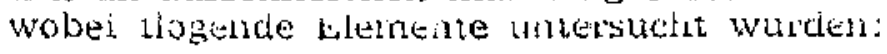

1) Ertrag des Grüntutler's und Heus per I Hektar;

2) Zusammensetzung und Klassifikation des Futters nach Deckungsgrad der einzelnen Arten sowie ihre ökonomische Bedeutung;

3) Chemische Zusammensetzung des IIeus;

4) Einfluss natülicher and anthropogener Faktoren auf die Entstehung und Entwicklung der einzelnen Typen; und

5) Meliorationsaussichten.

\section{Resuitate.}

1) Vom landwirtschaftlichen Standpunkt wurden folgende Typen (Assoziationen, Subassoziationen) untersucht:

a) Assoziation Bromus crectus-Plantago media

$$
\text { Subasisoziation Xerobrometurn }
$$

b) Assoziation Nardetum strictae

c) , Calluneto-Genistetum

d),$\quad$ Agrostidetum vulgaris

e) " $\quad$ Cynosuretum cristati

f) ", Arrhenatheretum elatioris.

Die Struktur und Entwicklung dieser Wiesen hängt von verschiedenen Faktoren ab. Die geologische Unterlage aus Kalkstein oder Silikat hat zufolge ihrer chemischen Zusammensetzung neben Feuchtigkeit, Klima und Nalrungsstolten einen grosisen Einfluss auf das physiognomische Aussehen, wie auch aut die Bildung der Pllanzenassoziationen. Das Aussehen, die Zusammensetzung und der Stand zahlreicher Assoziationen werden durch okologische Verhiltnisse und den Einfluss biotischer Faktoren bedingt.

2) Weiters wurde die quantitative und qualitative Zusammensetzung der einzelnen rypen untersucht. Labei wurde festgestellt, dass der Ertrag des Grünfutters und Heus in verschiedenen Typen verschieden ist und beträgt: Subassoziation Mes obromet um $9043 \mathrm{~kg}$ Grinfutter oder Heu $3.550 \mathrm{~kg}$

Assoziation Nardetum strictae $5290 \mathrm{~kg} \quad$ N $\quad$ " $\quad$ " 1.669 .. "Calluneto-Genistetum $3952 \mathrm{~kg} " \quad$ " $\quad 1.440$ "

"Agrostidetum vulgaris 14.069 $\mathrm{kg} "$ " 5.044 "

"Cynosuretum cristati $21.000 \mathrm{~kg} "$ " $7.000 "$

"Aluenatheretum elatioris $22.000 \mathrm{~kg} "$ " 6.832 "

Schwankungen innerhalb der Typen hängen von der Bearbeitungsart der betreffenden Flächen ab.

3) Unter den einzelnen Typen bestehen grosse Unterschiede im Gewichtsverhältnisse der einzelnen Komponenten: Leguminosen, Gräserm und übrigen Pflanzen. Dieses Verhältnis ist in den Graphikonen I., II., III., und IV., Seite 41 bis 44 dargestellt.

Dem landwirtschaftlichen Wert gemäss sind die Pflanzenarten In die Kategorien $A, B, C$, und $D$ eingerieiht. Dieses Verhältnis ist tabellarisch dargestellt und zwar: fij: den Typus Bromus erectus-Planitago media auf Seite 10, Nardetum sitrictae auf Seite 18-19, Agrostidetum-vulgaris auf Seite 23-25, Arrthenatheretum auf Seite $29-31$, Cynosuretrm auf Seite $32-34$. 
Der durch Wägen gewommene Deckungswert gibt ein Bild von der Wichtigkeit einzelner Arten und Gruppen in der Assoziation selust. Er ist. von grosser praktischer Bedeutung bei der Zusammensetzung von Grasmischungen fiir das betreffende Gebiet. Nach der floristischen Zusammensetzung in der Subassoziation Xerobrometum entfallt auf Gräser $19.56 \%$, auf Leguminosen $9.67 \%$, während in der Subassoziation Mesobrometum auf Gräser 22.46\%, auf Leguminosen $19,44 \%$ entfallen. In der Assoziairon Agrosticletum vulganis entfallen aut Gräser $55.4 \%$, auf Leguminosen I.7. $\%$ c.

In der Assoziation Cynosuretum clistati entfallen auf Grëser 31.77\%, ¿ate Leguminosen 22.53\%. In der Assoziation Arxhenatheretum elatioris cntfallen auf Gräser $29.57 \%$, auf Leguminosen $16.48 \%$.

4) Die botanische und chemische Analyse des Heus bietet, wichtige Elemente zur Beurteing des Wertes des Heus dar. zus Beurteilung des algemeinen Nährwertes des Heus ist dessen Verdaulichlseit, bezw. der Veratungskoelfizizient fuir die einzenen in in enthattenen Nahrstoffe notwendig. (Siehe Tabolle auf Seite 36-37).

5) Diese Wiesen entstanden als Folge der Verdrängung der Wälder oder der Auflassung von Kulturen unter Einfluss von Düngen. Die Assoziation Agrostidetum vulgaris ist eine Kulturwiese, bis zu einen gewissen Grad auch dis Trisetetum and das Arhenatheretum, withend die anderen natüiliche Wiesen darstellen.

6) Dio botanischen und landwirtschaftichen Untersuchungen ergaben, class sich alle Typen von Bergwiesen und Weiden durch michtig durchgewhite Melioration in arsgezeichnele Typen wo Tal - and Bcrgutiesen Arbonatheretum, Agrosidetum und Thistetum - ïberfühen lassen. Als beste Beabbeitungsunt der Assoziation Agrostidetum vulgaris wird nach dem Auflassen der Kulturen das Alwsiahen von geeigneten Gras- und Klemischungen, welche in djevem Tvpus mit dom grössten Deckungsgrad vertreten sind, emfohlen; dieseiben halxen eisen hohen Nährvert and sind den Lehensvehaitnissen des Standon tes angepasst. Die Zusammensetzung der Alten ist in der 'Tabelle beim Assoziatimstypus Agrosticterum vulgivis auf Seite $23-24$ angelithet.

7) Das Fudresultat der kombinierten botanischen und landwirtschaftItohen Unterswehmgen beweist, dass die natürlichen Gimeinschaften von Wieson und Weiden. wie sie von Botanikern dargestellt wutden, den einfachsten und sichersten Absangspunkt fin alle lindwirtschaftichen Unterstchunson bieten.

\section{I T E R A T U R A :}

1. Perl-Lunge: Chemisch-technische Untersuchungsmethoden. III Band. 1932.

2. B r a u $n-B$ i a $q$ u et J.: Pflanzensoziologie. Berlin, 1928.

3. Dordevíc V.: Livadarsivo sa pašnjarstvom. Beograd, 1951.

․ F a gan T. W. Wathius H. T. 1933.

The chemical composition of the Miscellaneous Herbs of Pastures Welsh Joum. of Agr. Vol. VIIt.

5. I orva t I.: Sociologija bilja i poljoprivreda. Glasnilk Ministarstva poljoprivrede 7, Beoglad, 1929.

6. Horvat I.: Vegetacijske studije o hrvatskim planinama. I, Zadruge na planinskim goletima. Rad. Akad. 238. Zagreb, 1930.

7. Hoy vat I.: Brdske livade i vristine u Hrvatskoj. Acta Bot. 7, 1931. 
8. Horvat I.: Biljne zadruge planinskih pašnjaka, Sum. priv. Zagr. 1946.

9. Horvat I.: Nauka o biljnim zajednicama. Zagreb, 1949.

10. Horvat I.: Istraživanje i kartiranje vegetacije planinskog skupa Risnjaka i Sniježnika. - Sumarski list, 1950.

11. Horvatić S.: Soziologische Einheiten der Niederungswiesen in Kroatien und Slavonien. Acta Bot. 5. Zagreb, 1930.

12. Fow $\mathrm{vat}$ ic $\mathrm{S}$.: Die venbreitetsten Pflanzengesellschaften der Wasser- und Ufervegetation in Kroatien und Slavonien. Acta Bot. 6. Zagreb, 1931.

13. Kellner-Fingerling: Grundzüge der Fütterungslehre. Berlin, 1950.

14. K va k a n P.; Uticaj mineralnih gnojiva na biljni sastav i prirod livada u Sasinoveu. Zagreb, 1944.

15. K,vakan P.: Trave. Zagreb, 1948.

16. Larin I. V.: IKormovie rastenia estestvenih senokosov i pastvišč SSSR. Moskva, 1937.

17. Mo ha ček M.: Surova vlakna i njihovo određivanje u krmivima. Znanstvena smotri, 1947.

18. Soroceanu E.: Réchèrches phitosociologique sur les pelouses mesoxerophiles de la Plaine longuedocienne (Brachypodietum phoenicoides) comm. Signa 41. Montpellier, 1936.

19. Stapledon G.: The nutritive Influence of the Herbs of Grassland The Magazine of farming 1./6. 1948.

20. Vil ja nis V, R.: Estestiveno naucenye osnovy lugovodstva ili lugovedenia.

21. Viljams V. R.: Nauka o zemljištu. Beograd, 1950.

22. Wissman H.: Agrikulturchemisches Praktikum - Quantitative Analyse Berlin, 1926. 